\title{
PERSONAL ASSETS, ACCESS TO CREDIT AND GENDER ENTREPRENEURIAL DISPARITIES: THE CASE OF THE SOUTH AFRICAN INFORMAL SECTOR ${ }^{1}$
}

KARINE CHAPELLE*

\begin{abstract}
This article aims to analyze the nature of South African entrepreneurship and to assess the extent to which obstacles and especially liquidity constraints faced by women may differ from those met by men during the phase of firm settlement. This study shows that women in the informal sector who are less educated and more burdened by unemployment are more "necessity-based" or "push" entrepreneurs than their male counterparts. They appear to have greater difficulty in accumulating sufficient personal assets than their male counterparts. They thus rely more often on stokvel or money lenders to access credit than men.
\end{abstract}

Keywords: Entrepreneurship, gender, access to credit, personal assets.

JEL Classification: G32, J7, J16, L26, M13.

\section{INTRODUCTION}

Since the post-Apartheid period, South Africa has made major progress in the defense and promotion of women's rights. According to the World Economic Forum's Gender Gap study (2006), which measures the gender gap in 115 countries (90 percent of the world population) in terms of economic participation, education, political power and health, South Africa now occupies the $18^{\text {th }}$ place with an overall parity rate of 71 percent $^{2}$. This pro-

* CREAM, Universities of Rouen and Le Havre, France.

1 I wish to thank STATA SA which has allowed me to merge these two surveys. Without its authorization and help, most of this study would not have been possible. I wish to also thank the anonymous referee for their fruitful comments and advise.

2 Taken separately, South Africa is: $79^{\text {th }}$ in the economic participation, $42^{\text {nd }}$ for education, $8^{\text {th }}$ for political power and 59th for health. See http:/ / www.weforum.org/pdf/gendergap/rankings.xls. 
motion of women in the workforce and also in society has resulted from the enactment of several laws aimed at curbing the different forms of both racial and gender inequalities. It first started in 1995 with the Labor Relations Act, and in 1997 with the Basic Conditions of Employment Act, which were promulgated to improve the working conditions of the general population. Theses acts were reinforced later on in 1998 by the Employment Equity Act, which emphasized and promoted equal opportunities and treatment, and in 2000 by the Promotion of Equality and Prevention of Unfair Discrimination Act, which was designed to fight against all forms of discrimination, harassment, and abuse of language. Finally, in 2003, the Broad Based Black Empowerment Act aimed to promote the integration of previously disadvantaged people in the management and control of the economy.

Despite all these measures ${ }^{3}$, as well as a more and more active participation of women in the workforce, in 2007 women only occupied around 19 percent of executive managerial positions and 13 percent of directorship positions in South Africa. Of the 310 largest companies listed on the Johannesburg Stock Exchange, only 8 women were at the head of these enterprises as Chief Executive Officers (CEOs) ${ }^{4}$. Moreover, in Minniti (2003), women's entrepreneurial rate ${ }^{5}$ in South Africa was 21 percent lower than that of their male counterparts. Finally, less than 10 percent of individual and family enterprises which employ less than 10 employees are owned by women. This entrepreneurial rate is low compared to the continental African context where women can account for a very important share of local entrepreneurship (Bardasi et al. 2007).

Consequently, this paper aims to shed light on the nature of business start-ups in South Africa, and to assess the extent to which obstacles and constraints faced by women may differ from those met by male entrepreneurs during the phase of firm settlement. This paper will focus on two aspects: the decision of starting a business; and the constraints on start-up capital.

These aspects have been chosen for three main reasons. First, authors like

${ }^{3}$ Other laws having an indirect relationship with the role of women in the economy have been enacted and had a role in the economic empowerment of women, such as the Choice on Termination of Pregnancy Act of 1996 authorizing abortion, the Domestic Violence Act of 1998 giving a broader definition of violence and the Recognition of Customary Marriages Act of 1998 promulgating the equality of status between the spouses in customary marriages.

4 South African Women in Corporate Leadership Census (2007), Businesswomen's Association of South Africa: http://www.bwasa.co.za/Portals/4/docs/archive/Women_in_Corporate_ Leadership_Census_2007.pdf.

5 Measured on 18-64 years old population. 
Holmes and Schmitz (1990), Holtz-Eakin et al. (1994a) (1994b), Lindh and Ohlsson (1998), Evans and Jovanovic (1989), Dunn and Holtz-Eakin (2000) have shown that personal wealth, along with access to credit, were two of the most important determinants of the decision of firm creation. Indeed, the decision for entrepreneurship is generally the result of a trade-off between wage earnings obtained in the labor market and expected revenues from entrepreneurship. Second, studying these two aspects makes it possible to analyze the impact of discriminatory practices that may affect women in the business world as well as in the labor world. Many studies have shown that gender, like race and ethnicity, is an important determinant of loan demand, and access to credit in terms of denial and loan conditions (Bates 1991, 1997; Carter and Allen 1997, Blanchflower et al. 1998, 2003, Cavalluzzo et al. 1998, 2002, Coate and Tennyson 1982, Aaronson et al. (2000), Fafchamps 2000, Menzies et al. 2006, Minitti and Narbone 2007, Muravyev et al. 2009, Robichaud et al. 2007). Because of discriminatory practices, women tend to modify the way they seek for funds. For Kon and Storey (2003), Marlow and Carter (2006), Irwin and Scott (2008) because they fear to have their demand for external resources refused, they are frequently discouraged to seek for capital. They therefore rely more on personal assets from friends and relatives and less on external resources of capital than their male counterparts (Brophy 1989, Brush 1992). Globally, they start with lower internal and external financial resources than their male counterparts. This may also explain, yet partially, why, as shown by Bardasi et al. (2007), women are more preponderant in family businesses than in individual enterprises.

Finally, independently of discriminatory practices, disparities in terms of personal assets and access to credit may reveal differences of motivations between men and women. According to Reynolds et al. (2002), enterprises may be of two kinds "necessity-based" or "opportunity-based" businesses. Indeed, following Amit and Muller (1994) and Amit et al. (1995), motivations for entrepreneurship are often dichotomized into "push" or "pull" categories. Some entrepreneurs have chosen self-employment for survival motives. Unemployment or under-employment, weak revenues and unstable jobs in the labor market have "pushed" them into entrepreneurship. Conversely, other entrepreneurs were "pulled" into entrepreneurship by the desire to be more independent, to pursue family know-how and tradition or to implement managerial or technological innovations into their firms. According to many studies like those of Orhan and Scott (2001), Kirkwood (2009), and Mitchell (2004), in the particular case of South Africa, there are no significant differences on motivations between male and female entrepreneurs. Yet, although men and women may be both motivated by "push" and "pull" 
factors, men and women seem to differ in the nature of their motivations. Conversely, for Wagner (2005), women explain more frequently than men do their decision to enter into entrepreneurship by push factors. They would be therefore more push entrepreneurs than their male counterparts. Since psychological features like motivations are important determinants of firm growth (Baum and Locke 2004), it can be assumed that these differences in motivations may also influence the level of assets and access to loans (Carter et al. 1997, Coleman 2000, Kon and Storey 2003, Marlow and Carter 2006, Korosteleva and Mickiewicz 2009).

Consequently, the overall purpose of this paper is to answer the following research questions:

1) Are women more "push" entrepreneurs than men, since they may be more affected by discrimination or by the glass ceiling effect in the labor market than their male counterparts?

2) Do women face stronger difficulties than men in acquiring personal assets?

3) Do women have lower access to loan than men?

In order to analyze these potential determinants of South African female entrepreneurship, this study has benefited from two surveys which have been merged: the September 2005 Labor Force Survey (LFS), which provides individual data on the labor force in South Africa, in particular, annual revenues and human capital; and the Survey of Employers and Self-employed (Sept. 2005, SESE), which provides data on enterprises owned by people surveyed in the LFS. The SESE survey is much more limited than the LFS in the sense that the SESE is based on people who, in the September 2005 LFS, responded that they were self-employed and whose enterprises were not recorded at the added tax value. Therefore, the SESE data only group private for-profit enterprises which may be considered as informal ${ }^{6}$. Yet the SESE

6 STATA SA considers a firm as informal when its economic activity occurs outside the purview of state regulation. With this VAT non registration criterion, more than 90 percent of these enterprises do not pay income tax or have no accountancy. Most of them operate without the required licenses and 90 percent of owners consider that their firm is informal. However, the LFS and SESE exclude activities which are designated as illegal such as narcotics trade and prostitution. Informal entrepreneurs are distinct from others only in their legal environment. There is no size criterion. However, they are characterized by an asymmetric firm size distribution in favor of micro enterprises. 96 percent of firms have less than 9 employees. Women are more likely or have smaller firms than men since 98 percent of women's owned enterprises compared to 94 percent of men's are micro-sized. Finally, they are essentially very young firms since 73 percent of firms have less than 5 years old and 88 percent less than 10 years old. Only 12 percent are mature firms. 
provides important information, notably on start-up capital formation and on entrepreneur's "push" and "pull" motivations for starting a business. One of the limit of studies on motivations like Orhan and Scott (2001), Mitchell (2004), Kirkwood (2009) is that since these studies are qualitative, they rely on few observations. (less than 100 observations). Moreover, for Mitchell (2004), in particular, the data only concerns entrepreneurs from the Northern Province of South Africa and who had obtained loans from the Get Ahead Financial Services. This may explain that no gender differences in motivations are observed. With data from South Africa Statistics, a total of 73,847 people was surveyed by the LFS in September 2005 from which 3,284 entrepreneurs from the informal sector were interviewed by the SESE7. The SESE has surveyed respectively 74 percent and 80 percent of LFS informal self-employed men and women i.e. 77 percent of the LFS informal self-employed persons. Although it is not possible to analyze formal entrepreneurship, the SESE is quite representative ${ }^{8}$ of the LFS informal self-employed population and concerns the nine Provinces of South Africa.

The remainder of the paper proceeds as follows. In sections 2 the differences in entrepreneurial entry between men and women will be examined through the study of entrepreneurial rates across sectors, human capital and race. In section 3, men and women's decision to become an entrepreneur is explored through the lens of motivations and earnings. These two sections will make it possible to highlight that women's informal entrepreneurship differs from that of men's in a considerable manner. Section 4 will study the capital constraints faced by men and women during the period of firm settlement in the informal sector. In particular, it will aim to shed light on the differences of sources and amounts of personal assets between men and women. It will also focalize its attention on the problem of men and women's access to credit and will aim to assess the extent to which the credit constraints faced by women may differ from those met by men entrepreneurs. Finally, section 5 will discuss the results limitations.

7 Since some entrepreneurs have more than one business, the SESE has sometimes surveyed up to three enterprises by the same entrepreneurs. A total of 3,372 non-VAT-registered enterprises has been surveyed.

8 Only 26 percent of informal Indian-Asian women from the informal sector were surveyed by the SESE. This implies that all the results concerning the Indian-Asian women must be analyzed with caution. Conversely Table 2 shows that human capital distribution of the SESE population compared to that of the LFS informal self-employed distribution is homogeneous. 


\section{INFORMAL ENTREPRENEURSHIP IN SOUTH AFRICA}

It is generally acknowledged that women are a source of reserve growth and development for many developing countries. Women would increase the competitiveness of economies in the private sector and would create jobs in economies characterized by massive underemployment (Bardasi et al. 2007). Despite the role that is or could be played by women in the economy, it is established that, in many developed countries as in many developing countries, the share of female entrepreneurship is often lower than that of men. South Africa is an exception. The data from the LFS (2005) show that men's and women's entrepreneurship rates are equal to 12 percent (see Table 1: columns and note (g) $)^{9}$. Like in Herrington et al. (2005), women are as likely as men to start a business ${ }^{10}$. However, the employment status distributions of both genders are not homogeneous. The Pearson F-test (See Table1: note (i); Column (1) F=201.44) indicates that the employment status distributions of men and women are significantly different at a 1 percent level. Indeed, women are more affected than men by unemployment since 45 percent of women are unemployed in comparison to 31 percent of men and only 44 percent of women are employed in contrast to 57 percent of men. Therefore, the particularity of South Africa is that despite women's lower access to job, women do not conceive of or are not able to choose entrepreneurship as a way to escape from unemployment contrary to what probably can be observed in the rest of the African continent. Yet, those gender entrepreneurial rates hide strong significant racial and sectoral ${ }^{11}$ differences. If African-col-

9 Yet, when the figures are not rounded, we obtain that women's rate is slightly lower than that of men i.e. 11.75 percent of women and 11.82 percent of men have opted for entrepreneurship. These rates are measured on the population surveyed by LSF that are more than 18 years old. Discouraged job seekers are taken into account in the measure of the labor force. These persons have been added in the labor force since we are studying "push" entrepreneurship. The fact that these persons have abandoned the hope to find a job signifies that they also have abandoned the idea to start an enterprise as a means to struggle against unemployment. Neglecting this population would overestimate the total entrepreneurial rates (see Table 1).

10 Based on GEM adult population survey which has? interviewed 2,761 adults between 18 and 64 years old, in seven provinces of South Africa. No indications are given concerning the legal status of sector (formal and informal).

11 The SESE only groups for-profit private firms which are not Value Added Tax (VAT) registered. According to the LFS information, most of these enterprises (i.e. more than 90 percent of Non-VAT registered businesses) do not have an accountability and are not registered, Moreover, although the SESE selection of firms was not based on size segmentation, the majority of SESE entreprises are micro firms, i.e. less than 5 employees. Therefore, the entrepreneurs surveyed by the SESE own firms which can be considered as informal entreprises; In order to be consistent 
ored men and women have quite equivalent entrepreneurial rates i.e. around 15 percent in the informal sector and 1 percent in the formal sector (see Table 1: columns and note (e)), White as well as Indian-Asian men have higher entrepreneurial rates than their female counterparts, regardless of the sector. According to the Pearson F-test (see Table 1: note (i), columns (2)), regardless of the sector and race, the distributions between gender are significantly different at a 1 percent level for the Non-White populations and a 10 percent level for the White population. It is interesting to notice that, when the unemployment category is not taken into account, i.e. the distributions are measured between the employment and self-employment statuses, there are no gender differences in the distributions, regardless of the sector (see Table 1: note (i), columns (3)). This implies that behind differences in entrepreneurial rates, there are strong differences in unemployment rates. More surprising, even in the informal sector, White men and women have the highest entrepreneurial rates. The Pearson F-tests between races indicate that for both men and women, the employment status distributions between races are heterogeneous at a 1 percent level of significance, regardless of the way the distribution is measured (See Table 1, note (i), columns (2) and (3)). Yet, in accordance with what is generally acknowledged, regardless of race and gender, the highest entrepreneurial rates are observed in the informal sector suggesting that entrepreneurial entry in that sector seems to be easier than in the formal sector. Finally, respectively 73 percent and 93 percent of self-employed men and women work in the informal sector. Like in many emerging African countries, the informal sector is dominant in the South African economy and female entrepreneurs are more concentrated than their male counterparts in the informal sector.

These gender entrepreneurial disparities may be attributed to differences in human capital. According to Davidsson and Honig (2003), individuals with higher human capital, i.e. education and professional experience, may have better knowledge of markets and business practices, and may better identify business opportunities than their less qualified counterparts. According to Ucbasaran and al. (2004), Evans and Leighton (1989) and Wit and Van Winden (1989), people with higher levels of human capital are, therefore, more likely to start a business than their less qualified counterparts. This suggests that self-employed people should have higher education than their employed counterparts. Yet, according to Bohla et al. (2006), and Evans

with the SESE definition of the informal sector, I have defined, the formal sector as a sector which encompasses for-profit VAT registered enterprises, non-profit and non-governmental organizations as well as public enterprises. 


\begin{tabular}{|c|c|c|c|c|c|c|c|c|c|c|}
\hline 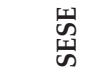 & 후 & 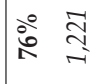 & 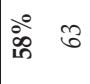 & ఏి & 犬े & 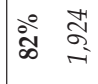 & ஷें 요 & $\stackrel{\AA}{\stackrel{\circ}{\circ}} \wedge$ & 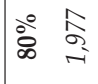 & 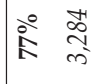 \\
\hline 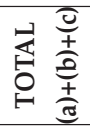 & क्र & $\begin{array}{ll}\stackrel{0}{0} & \stackrel{0}{2} \\
\stackrel{0}{0} & \stackrel{2}{2}\end{array}$ & 总 & 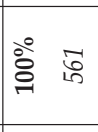 & 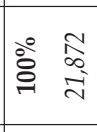 & 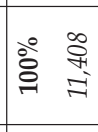 & 高 & ळे ฌి & 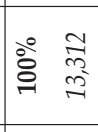 & 今े \\
\hline$\stackrel{\infty}{g}$ & 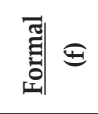 & 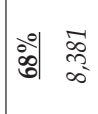 & :ूे & 斊 & ભำ 㞼 & హे $\underset{20}{2}$ & 의 స్ & ㅎํㄴ 유 & 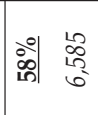 & : \\
\hline 劉 & 预 $\Xi$ & ڤેे| స్ సે & ळl 넘 & 今े & ฟิํำ & 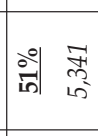 & ڤั & ปे స & 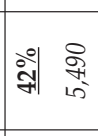 & 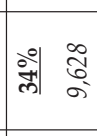 \\
\hline & 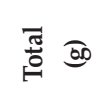 & 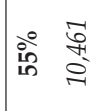 & $\stackrel{\circ}{\stackrel{\leftrightarrow}{ }} \stackrel{ }{\rightarrow}$ & ڤั & 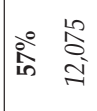 & 今్ & :̊̊ & : & ‡ें & 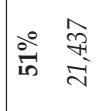 \\
\hline 这 & 畺 & ڤ̊ำ & : & ळे| ळे ळે & $\begin{array}{lc}0 \\
\vdots \\
\infty\end{array}$ & 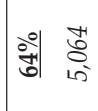 & ì & ㅊํำ 궈 & 웨 & 商 \\
\hline & 罵 $\Theta$ & : & 웍 in & ถ̊ำ & : & :্ল & iol in & ळे $\wedge$ & ذి & ๙ิ) \\
\hline & 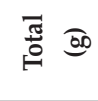 & 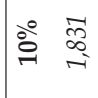 & $\stackrel{\circ}{\circ}$ & $\stackrel{\circ}{\vec{\gamma}} \stackrel{?}{\exists}$ & 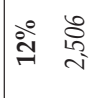 & ‡ั & $\stackrel{\circ}{\sharp}$ & iे $\bar{~}$ & 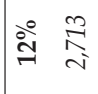 & 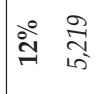 \\
\hline 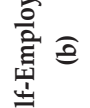 & 固 & $\stackrel{10}{7} \stackrel{0}{1}$ & 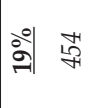 & i̊ำ & ஓे : & 워 7 & ळ๐ & ล้ ส & $\Rightarrow$ 의 & ڤे \\
\hline ஸ & 窵 & $\because$ & : & 离 & ڤ̊ & iำ 壳 & ‡ั๋ & 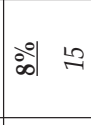 & : & 웡 \\
\hline 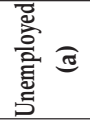 & ब्र & 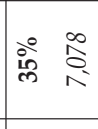 & ๑े స్ & $\stackrel{\circ}{\grave{A}}$ & $\stackrel{\circ}{\bar{m}}$ & హे ฮे & $\stackrel{\circ}{\Rightarrow}$ & 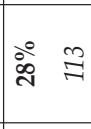 & 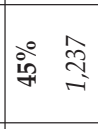 & 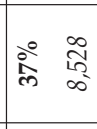 \\
\hline \multirow[t]{2}{*}{ tr } & \multirow[t]{2}{*}{ 岂 } & 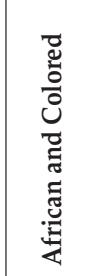 & 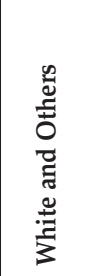 & 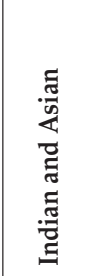 & 褐 & 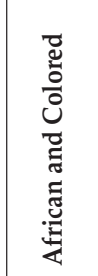 & 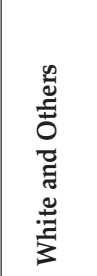 & 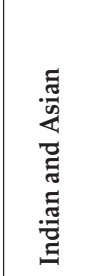 & 沓 & \multirow[t]{2}{*}{$\underset{\stackrel{\vec{E}}{\circ}}{\overrightarrow{0}}$} \\
\hline & & & \multicolumn{4}{|c|}{ NaWOM } & \\
\hline
\end{tabular}


NB:

(a) The official definition of unemployment is "all persons aged 15-65 who did not have a job or business in the seven days prior to the survey interview but had looked for work or taken steps to start a business in the four weeks prior to the interview and were able to take up work within two weeks of the interview"*. This definition considers that unemployed people aged 15-65 who are not seeking a job for any kind of reasons do not belong any more to the labor force. In the SESE, people above 65 years old were interviewed. In order to keep all the available information, the labor force is defined in this article as to embrace all active persons above 65 years old (see note (f)). Moreover, I have added in the unemployment population, and therefore in the labor force, all persons who had not taken any action to find any occupation because:

- s)he is temporarily laid off work, unable to find work requiring his/her skills,

- s)he is lacking money to pay for transport to look for work,

- no jobs or transports are available in the areas,

- s)he had lost hope in finding any kind of occupation", (see questionnaire LFS, 2005).

Consequently, among 73,847 persons surveyed by September 2005 LFS, only 43,842 persons are considered as belonging to the labor force.

(b) Self-employment groups persons aged at least 15 who are "working on their own or with a partner in any type of business including commercial farming) in the seven days prior to the survey interview or will start running a business at a definite date in the future" (LFS, 2005, see questionnaire).

(c) All persons aged of at least 15 years old who "did any work or who did not work but had a job or business in the seven days prior to the survey interview or will start working at a definite date in the future" are considered as employed (LFS 2005, see questionnaire).

(d) The percentages in the SESE column account for the shares of the non VAT entrepreneurs interviewed in the LFS, who were surveyed by the SESE.

(e) For the self-employed columns, the percentages for both sectors are proxies of entrepreneurial rates i.e.

$$
E R i=\frac{\text { Number of Self-Employed in Sector } i}{\text { Number of working people in Sector } i+\text { Unemployed }}
$$

These rates are more pertinent if it is assumed that (in)formal wage earners take their decision to create an entrepreneur within the same sector. This assumption is not irrelevant since few (self)-employed person mute from one sector to another.

(f) The percentages account for the share of people employed (working) respectively in the informal and formal sector. Therefore, the addition of these two percentages is equal to 100 percent.

(g) All the other percentages account for the share of the labor force which is (un)(self-)employed over total labor force.

(h) Author's computations: In bold, weighted shares. In italic, unweighted number of observations

(i) Pearson test of homogeneous employment status distribution between:

\footnotetext{
* See Lehohla (2006) for the official definition of active population and of unemployment.
} 


\begin{tabular}{|c|c|c|c|c|c|c|}
\hline \multirow{2}{*}{\begin{tabular}{|l|} 
Pearson test \\
between \\
\end{tabular}} & \multirow{2}{*}{$\begin{array}{c}\text { for } \\
\text { Categories } \\
\text { in the test }\end{array}$} & \multirow{2}{*}{\begin{tabular}{|c|} 
Total \\
Unemployment (U) \\
Employment (E) \\
Self-Employment- (SE) \\
(1)
\end{tabular}} & \multicolumn{2}{|c|}{ Informal } & \multicolumn{2}{|c|}{ Formal } \\
\hline & & & $\begin{array}{c}\text { U-E-SE } \\
(2)\end{array}$ & $\begin{array}{c}\text { E-SE } \\
(3)\end{array}$ & $\begin{array}{l}\text { U-E-SE } \\
(2)\end{array}$ & $\begin{array}{c}\text { E-SE } \\
(3)\end{array}$ \\
\hline \multirow[t]{4}{*}{ gender } & Colored-African & $213.38^{* * *}$ & $5.79^{* * *}$ & 0.48 & $209.46^{* * *}$ & 0.42 \\
\hline & White and Others & $25.28^{* * *}$ & $2.82^{*}$ & 0.63 & $32.50^{* * *}$ & $56.02^{* * *}$ \\
\hline & Indian and Asian & $23.72^{* * *}$ & $7.70^{* * *}$ & 0.04 & $28.25^{* * *}$ & $35.62^{* * *}$ \\
\hline & total & $201.44^{* * *}$ & $8.48^{* * *}$ & 0.024 & $286.45^{* * *}$ & $28.38^{* * *}$ \\
\hline \multirow[t]{3}{*}{ race } & Men & $99.10^{* * *}$ & $10.17^{* * *}$ & $9.20^{* * *}$ & $261.44^{* * *}$ & $239.96^{* * *}$ \\
\hline & Women & $95.19^{* * *}$ & $4.56^{* * *}$ & 1.58 & $168.12^{* * *}$ & $35.16^{* * *}$ \\
\hline & Total & $122.09^{* * *}$ & $9.12^{* * *}$ & $9.24^{* * *}$ & $287.34^{* * *}$ & $195.04^{* * *}$ \\
\hline
\end{tabular}

The Pearson chi-squared statistic is corrected for the survey design (H0: homogeneity of distributions between group 1 and group 2). It is thus converted into an F statistic.

Column (1) tests the homogeneity of distributions presented by columns (g) in Table 1.

The two columns (2) test the homogeneity of distribution presented by columns (e) in Table 1. Since, by definition, unemployed people can belong neither to the formal sector nor to the informal sector, tests in columns (2) take into account the unemployed population, which makes it possible to test the differences of formal and informal entrepreneurial.

The two columns (3) test the homogeneity distribution presented by columns ( $\mathrm{g}$ ) in Table 1 without unemployed people.

(j) ${ }^{* * *}$ significant at 1 percent; ** significant at 5 percent; * significant at 10 percent.

and Leighton (1990), people with low level of human capital have less access to paid job and are more likely to start a business in order to escape from unemployment or under-employment than their highly educated counterparts. All this suggests that education may have ambiguous effects on entrepreneurship. According to Table 2, in the informal sector, regardless of gender, informal entrepreneurs seem to be more educated than their employed counterparts (see Table 2: total representativity index (a)). 68 percent of informal self-employed people have achieved at least secondary education compared to 65 percent of their employed counterparts ${ }^{12}$. The homogeneity tests indicate that for both genders, the education distributions of the self-employed and employed populations are not significantly homogeneous at a 1 percent

12 In the formal sector, the same phenomenon is observed. 98 percent of self-employed men and women have at least a secondary education compared to 87 percent of their employed counterparts. 
level. Education stimulates entrepreneurship for both genders. Yet, the impact of education on men's entrepreneurship is more important than on women's entrepreneurship. The shares of self-employed men and women with superior education are respectively 3.5 and 2 times higher than those of their employed counterparts (see Table 2: representativity index (b)). The Pearson F-test indicates that, at a 1 percent level of significance, self-employed men and women do not present the same education distribution. This comes from the fact that informal female entrepreneurs are less educated than their male counterparts (see Table 2: representativity index (c)). 72 percent of male entrepreneurs compared to 63 percent of female entrepreneurs have at least secondary schooling while 9 percent and 15 percent of male and female entrepreneurs have not received any education. Gender seems to have a significant impact on entrepreneurs' education distribution. This type of disparities also appears with racial attributes. More than 95 percent of White and Indian-Asian entrepreneurs have at least attained secondary education compared to 66 percent of African-Colored self-employed men and women. African-Colored informal entrepreneurs are, therefore, less educated than their White and Indian-Asian counterparts. The Pearson F-tests indicate that Non-White entrepreneurs do differ from their White counterparts in terms of education at a 1 percent level of significance (see Table2: representativity index $(\mathrm{d})$ ).

All these results from tables 1 and 2 suggest that, in South Africa, race and gender which are attributes that can give rise to discriminations continue to be important determinants of informal entrepreneurship as they appear to reduce the entrepreneurial rates of discriminated-against groups. Yet education in combination with gender and race seems also to segment South Africa entrepreneurship. The question is how? In order to examine this question, we need to understand people's decision to start a business.

\section{THE PRESENCE OF GENDER DUALISM}

For authors like Amit and Muller (1994) and Amit et al. (1995), Brush (1999), Buttner and Moore (1997), Reynolds et al. (2002), and Acs (2006), the decision of becoming an entrepreneur is explained by different motives or aspirations which can be classified as either opportunities or necessity. This classification conduces to distinguish two kinds of entrepreneurial creations: one being a necessity because of glass ceiling, job dissatisfaction or of lack of employment or revenues, i.e. "push entrepreneurship", the other being an opportunity to implement managerial and/or technical innovations, to have 
Table 2: Distribution of the self-employed labor force by gender, race and education (LFS,SESE 2005)

\begin{tabular}{|c|c|c|c|c|c|c|}
\hline & $\begin{array}{c}\text { No } \\
\text { Education }\end{array}$ & $\begin{array}{c}\text { Primary } \\
\text { Education }\end{array}$ & $\begin{array}{l}\text { Secondary } \\
\text { Education }\end{array}$ & $\begin{array}{c}\text { University } \\
\text { or Other } \\
\text { Superior } \\
\text { Education }\end{array}$ & Total & Fcal \\
\hline Informal Self-employed & $12 \%$ & $20 \%$ & $62 \%$ & $6 \%$ & $100 \%$ & \\
\hline Informal Employed & $12 \%$ & $23 \%$ & $63 \%$ & $2 \%$ & $100 \%$ & \\
\hline Total Representativity Index (a) & 1.041 & 0.886 & 0.979 & 2.680 & 1.000 & $10.78^{* * *}$ \\
\hline Male Representativity Index (b) & 0.817 & 0.770 & 1.043 & 3.468 & 1.000 & 12.40 ** \\
\hline Female Representativity Index (b) & 1.221 & 0.997 & 0.925 & 2.024 & 1.000 & $5.64^{* * *}$ \\
\hline Informal Self-Employed Men & $9 \%$ & $19 \%$ & $65 \%$ & $7 \%$ & $100.00 \%$ & \\
\hline Informal Self-Employed Women & $15 \%$ & $22 \%$ & $59 \%$ & $4 \%$ & $100.00 \%$ & \\
\hline Representativity Index (c) & 0.626 & 0.861 & 1.099 & 1.632 & 1.000 & $8.70 * * *$ \\
\hline $\begin{array}{l}\text { African and Colored Informal } \\
\text { Entrepreneurs }\end{array}$ & $13 \%$ & $22 \%$ & $62 \%$ & $4 \%$ & $100 \%$ & \\
\hline $\begin{array}{l}\text { White and Others Informal } \\
\text { Entrepreneurs }\end{array}$ & $0 \%$ & $0 \%$ & $60 \%$ & $40 \%$ & $100 \%$ & \\
\hline $\begin{array}{l}\text { Indian and Asian Informal } \\
\text { Entrepreneurs }\end{array}$ & $3 \%$ & $2 \%$ & $92 \%$ & $3 \%$ & $100 \%$ & \\
\hline $\begin{array}{l}\text { African-Colored Representativity } \\
\text { Index (d) }\end{array}$ & 1.131 & 1.216 & 1.008 & 0.742 & 1.000 & $100.45^{* * *}$ \\
\hline $\begin{array}{l}\text { Indian-Asian Representativity } \\
\text { Index }(d)\end{array}$ & 1.031 & 1.023 & 1.195 & 0.737 & 1.000 & $15.62 * * *$ \\
\hline $\begin{array}{l}\text { Informal Self-employed } \\
\text { (without SESE) }\end{array}$ & $12 \%$ & $19 \%$ & $62 \%$ & $6 \%$ & $100 \%$ & \\
\hline SESE Informal Self-employed & $12 \%$ & $20 \%$ & $62 \%$ & $5 \%$ & $100 \%$ & \\
\hline Representativity Index (e) & 0.976 & 0.953 & 1.002 & 1.217 & 1.000 & 0.32 \\
\hline
\end{tabular}


NB:

(a) A representativity index superior to one indicates an over-representativity of the informal self-employed distribution of gender $j$ compared with the informal employed distribution of gender $j$

The representativity index of gender $j$ of race $i$ with education $k$ is measured the following way:

$R I_{S E / E, j k}=\frac{\text { Share of Informal Self-Employed people of gender } j \text { with education } k}{\text { Share of Informal Employed people of gender } j \text { with education } k}$

(b) A representativity index superior to one indicates an over-representativity of the informal self-employed distribution compared with the formal self-employed distribution

The representativity index of gender $j$ of race $i$ with education $k$ is measured the following way:

$R I_{I / F, j k}=\frac{\text { Share of Informal Self-Employed with education } k}{\text { Share of Formal Self-Employed with education } k}$

(c) A representativity index superior to one indicates an over-representativity of informal men's self-employed distribution compared with informal women's self-employed distribution.

The representativity index of gender $j$ of race $i$ with education $k$ is measured the following way:

$R I_{M / F, j k}=\frac{\text { Share of Informal Self-Employed Men with education } k}{\text { Share of Informal Self-Employed Women with education } k}$

(d) A representativity index superior to one indicates an over-representativity of the informal Self-Employed distribution of race $i$ compared with the White informal self-employed distribution.

The representativity index of gender $j$ of race $i$ with education $k$ is measured the following way:

$R I_{i / \text { Whites, } j k}=\frac{\text { Share of Informal Self-Employed people of race i with education } k}{\text { Share of Informal Self-Employed of White people with education } k}$

(e) A representativity index superior to one indicates an over-representativity of the SESE distribution compared with LFS informal self-employed distribution.

The representativity index of gender $j$ of race $i$ with education $k$ is measured the following way:

$R I_{i / j k}=$

Share of Informal Self-Employed with education $k$

Share of SESE Informal Self-Employed with education $k$

(f) Author's computation: Weighted shares in bold. In Stata 11, when the Pearson chi-squared statistic is corrected for the survey design (H0: homogeneity of distributions between group 1 and group 2) it is converted into an F statistic.

(g) *** significant at 1 percent; ${ }^{* *}$ significant at 5 percent; * significant at 10 percent. 
a more independent professional life, or to continue family tradition or knowhow i.e. "pull entrepreneurship". According to Ucbasaran and al. (2004), Evans and Leighton (1989) and Wit and Van Winden (1989), highly educated people are more likely to be "pulled" into entrepreneurship whereas low educated people may be obliged to start a business for survival necessity (Bohla et al 2006, Evans and Leighton 1990). The fact that "pull" entrepreneurs are more likely to detect business opportunities than their "push"counterparts may imply that their decision to start a business is taken by comparing the differences of expected earnings between the two employment statuses contrary to "push" entrepreneurs. Indeed, according to Holmes and Schmitz (1990), Holtz-Eakin et al. (1994a) (1994b), Lindh and Ohlsson (1998), Evans and Jovanovic (1989), Dunn and Holtz-Eakin (2000), the decision to start a business is based on a trade-off between revenues earned by investing a portion of the entrepreneur's personal wealth into a firm's creation and income obtained during a wage earning activity. All things being equal, firm creation is decided when the expected revenues from entrepreneurship are higher than those obtained from the labor world. Thus, as the difference between wage earnings and entrepreneurship expected revenues declines, the probability of entering into entrepreneurship should increase. Therefore, when the decision for pull entrepreneurship is not related to non-pecuniary entrepreneurial benefits (like personal achievement, freedom, time flexibility...), it should be sensitive to earnings disparities between the two employment statuses. Yet, in developed countries and even more in developing countries, the real trade-off is generally not between employment and entrepreneurship. "Push" entrepreneurship and unemployment may be the real alternatives which people are confronted with. Therefore, entrepreneurship is not the 'Eldorado' for innovative entrepreneurs who wish to take better advantage of their managerial or technical skills (Verheul et al. 2008, Glocker and Steiner 2007, Rissman 2003). It is at most a shelter and at least the unique solution to find survival revenues. Consequently, people's decision to start a business does not result from a trade-off between revenues earned from employment and self-employment. The decision for "push" entrepreneurship is less likely to be influenced by differences in employment status earnings. If so, one can expect that women - who are less educated and more likely to be "push" entrepreneurs than their male counterparts - should be characterized by lower earning disparities between employment and self-employment compared to those of their male counterparts. Finally, since "pull" entrepreneurs are more highly educated entrepreneurs and more likely or capable to seek business opportunities, they should earn higher entrepreneurial revenues than their "push" counterparts. 


\section{Figure 1: Gender dualism}

\section{Hypothesis 1:}

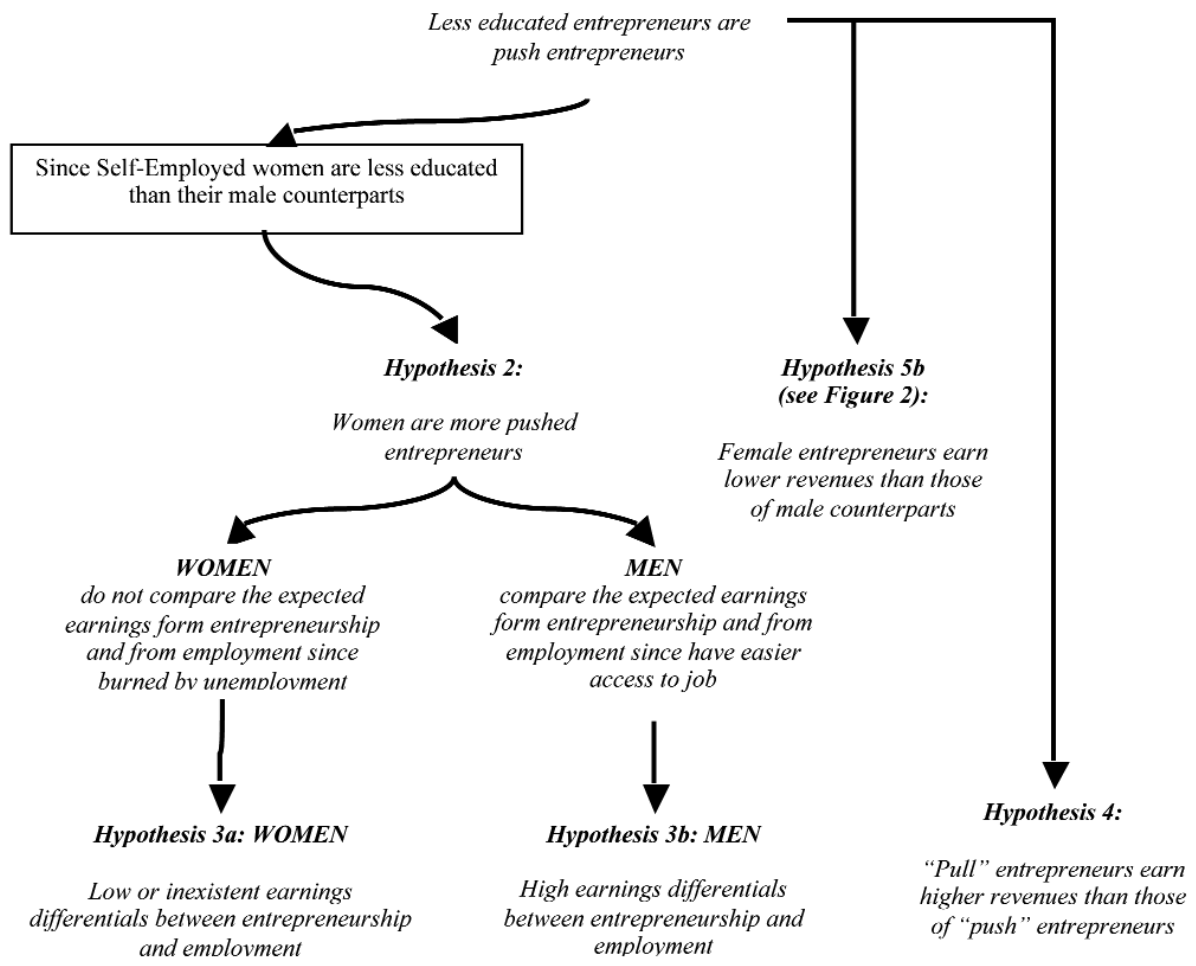

To summarize, I expect that high educated people are more likely to become "pull" entrepreneurs whereas low educated entrepreneurs are more likely to become "push" entrepreneurs. This assumption has two implications. The first implication is that "pull" entrepreneurs should earn higher revenues than their "push" counterparts. The second implication is that, since women are less educated, they should be more pushed entrepreneurs than their male counterparts. This leads to the following hypotheses (see Figure 1):

Hypothesis 1: Low educated people are more likely to be pushed than "pulled" entrepreneurs whereas high educated people are more likely to become pull entrepreneurs. 
Table 3: Education distribution of "pull" and "push" entrepreneurship by gender (SESE, 2005)

\begin{tabular}{|c|c|c|c|c|c|c|c|}
\hline $\begin{array}{l}\text { 䓢 } \\
\text { 惫 } \\
\text { }\end{array}$ & $\begin{array}{l}\text { Type of } \\
\text { entrepreneurship }\end{array}$ & $\begin{array}{c}\text { No } \\
\text { Education }\end{array}$ & $\begin{array}{c}\text { Primary } \\
\text { Education }\end{array}$ & $\begin{array}{l}\text { Secondary } \\
\text { Education }\end{array}$ & $\begin{array}{c}\text { University } \\
\text { or Other } \\
\text { Superior } \\
\text { Education }\end{array}$ & Total & F-stat \\
\hline \multirow{3}{*}{ 岁 } & Total "push" & $13 \%$ & $21 \%$ & $63 \%$ & $4 \%$ & $100 \%$ & \\
\hline & "Pull" & $10 \%$ & $17 \%$ & $62 \%$ & $12 \%$ & $100 \%$ & \\
\hline & Representativity index (a) & 1,253 & 1,254 & 1,020 & 0,314 & $100 \%$ & 13.14 *** \\
\hline \multirow{3}{*}{ 至 } & Total "push" & $9 \%$ & $19 \%$ & $68 \%$ & $5 \%$ & $100 \%$ & \\
\hline & "Pull" & $7 \%$ & $14 \%$ & $66 \%$ & $14 \%$ & $100 \%$ & \\
\hline & Representativity index (a) & 1,343 & 1,331 & 1,032 & 0,334 & $100 \%$ & $6.60 * * *$ \\
\hline \multirow{3}{*}{$\begin{array}{l}z \\
\sum_{0}^{2} \\
3 \\
3\end{array}$} & Total "push" & $15 \%$ & $23 \%$ & $59 \%$ & $3 \%$ & $100 \%$ & \\
\hline & "Pull" & $14 \%$ & $20 \%$ & $57 \%$ & $10 \%$ & $100 \%$ & \\
\hline & Representativity index (a) & 1,124 & 1,157 & 1,031 & 0,311 & $100 \%$ & $5.35 * * *$ \\
\hline
\end{tabular}

(a) Representativity index of gender i and education $\mathrm{j}$ :

$$
R I_{i j}=\quad \begin{gathered}
\text { Share of total Push entrepreeurship of gender } i \text { and education } j \\
\text { Share of Pull entrepreeurship of gender } i \text { and education } j
\end{gathered}
$$

(b) Total Push Entrepreneurship = " unemployed/have no other alternative income source " + "retrenched" + "Inadequate income from Other Sources" + "Unhappiness with previous word" + "Other reasons"

(c) Pull Entrepreneurship = "Inheritated/family tradition" + "I like the activity" + "I have the skills for this business" + "I have the equipment for this business" + "Activity brings high income" + "Small investment needed" SESE, 2005, questionnaire)

(d) Author's computation: Weighted shares in bold. In Stata 11, when the Pearson chi-squared statistic is corrected for the survey design (H0: homogeneity of distributions between group 1 and group 2) it is converted into an F statistic.

*** significant at 1 percent; ** significant at 5 percent; * significant at 10 percent.

In order to analyze the presence of "push" and "pull" entrepreneurships, the SESE has questioned informal entrepreneurs on their motivations for starting-up an enterprise. Table 3 presents the education distributions by type of entrepreneurships and by gender. It appears that, regardless of gender, "push" entrepreneurs with less than secondary education are over-represented compared to "pull" entrepreneurs. This over-representativity is statistically significant at a 1 percent level, regardless of gender. Therefore, the fact that self-employed women are less educated than their male counterparts suggests the following hypotheses: 
Hypothesis 2: Women should be more "push" entrepreneurs than their male counterparts.

According to Table 4, it appears that in the informal sector, 62 percent of men and 71 percent of women have chosen self-employment to address their problem of unemployment or underemployment. Unemployment constitutes the main entrepreneurial motivation among men and women. However, this predominance is more important among women than among men. The other reasons for being "pushed" into entrepreneurship respectively account for 14 percent and 10 percent of men and women's involvement. As for "pull" factors, they account for 24 percent of men's motivations compared with 19 percent for women. Like in Mandelman and Montes-Rojas (2009), self-employment is, for a majority of informal entrepreneurs, "disguised unemployment". The Pearson F-test indicates that, women's distribution between "total push" and "pull" entrepreneurships is significantly different from that of men at a 1 percent level (see Table 4: note (d), F=10.69). Globally, women are more pushed entrepreneurs than their male counterparts. Contrary, to Mitchell (2004), there are motivation disparities between men and women. The differences in results may come from the fact that Mitchell (2004) had only surveyed 101 entrepreneurs who were located in the Northern Province of South Africa. The SESE, on the contrary, has interviewed 3,284 entrepreneurs that are representative of the 9 provinces of South Africa. Finally, in Mitchell (2004), only entrepreneurs who had obtained loans from the Get Ahead Financial Services were surveyed. In the SESE, all entrepreneurs, regardless of their access to saving and credit were questioned.

Moreover, except for the Indian-Asian population ${ }^{13}$, women's distributions between "total push" and "pull" entrepreneurships are significantly different from those of men at a 1 percent level (see Table 4: note (d), Column Total). Specifically African-Colored women are globally more "push" entrepreneurs than their male counterparts (see Table 4). Yet, White women present a particular case. They are more "pull" entrepreneurs than their male counterparts. This may be explained by the fact that, since White "pull" male entrepreneurs are more likely to create their business in the formal sector rather than in the informal sector, White "push" male entrepreneurs might be over-represented in the informal sector compared to White "pull" selfemployed women.

13 Yet, this exception may be due to the fact that the Indian-Asian population accounts for insufficient observations. 
Table 4: Reasons for starting up business (SESE, 2005)

\begin{tabular}{|l|c|c|c|c|c|c|c|c|}
\hline & \multicolumn{4}{|c|}{ MEN } & \multicolumn{4}{c|}{ WoMEN } \\
\cline { 2 - 9 } $\begin{array}{l}\text { What was the main } \\
\text { reason you started } \\
\text { this business? }\end{array}$ & $\begin{array}{c}\text { African } \\
\text { and } \\
\text { Colored }\end{array}$ & $\begin{array}{c}\text { White } \\
\text { and } \\
\text { Other }\end{array}$ & $\begin{array}{c}\text { Indian } \\
\text { and } \\
\text { Asian }\end{array}$ & Total & $\begin{array}{c}\text { African } \\
\text { and } \\
\text { Colored }\end{array}$ & $\begin{array}{c}\text { White } \\
\text { and } \\
\text { Other }\end{array}$ & $\begin{array}{c}\text { Indian } \\
\text { and } \\
\text { Asian }\end{array}$ & Total \\
\hline $\begin{array}{l}\text { Total "push" } \\
\text { entrepreneurship (a)+(b) }\end{array}$ & $77 \%$ & $\mathbf{6 7 \%}$ & $\mathbf{6 5 \%}$ & $76 \%$ & $\mathbf{8 3} \%$ & $\mathbf{4 2} \%$ & $\mathbf{8 1} \%$ & $\mathbf{8 1 \%}$ \\
\hline "Push" entrepreneurship (a) & $63 \%$ & $51 \%$ & $57 \%$ & $62 \%$ & $73 \%$ & $13 \%$ & $76 \%$ & $71 \%$ \\
\hline $\begin{array}{l}\text { Other "push" } \\
\text { entrepreneurship (b) }\end{array}$ & $14 \%$ & $16 \%$ & $8 \%$ & $14 \%$ & $9 \%$ & $29 \%$ & $5 \%$ & $10 \%$ \\
\hline "Pull" entrepreneurship (c) & $23 \%$ & $33 \%$ & $35 \%$ & $24 \%$ & $17 \%$ & $58 \%$ & $19 \%$ & $19 \%$ \\
\hline Total (a)+(b)+(c) & $100 \%$ & $100 \%$ & $100 \%$ & $100 \%$ & $100 \%$ & $100 \%$ & $100 \%$ & $100 \%$ \\
\hline Unspecified & $0 \%$ & $0 \%$ & $0 \%$ & $0 \%$ & $0 \%$ & $2 \%$ & $0 \%$ & $0 \%$ \\
\hline TOTAL & $100 \%$ & $100 \%$ & $100 \%$ & $100 \%$ & $100 \%$ & $100 \%$ & $100 \%$ & $100 \%$ \\
\hline
\end{tabular}

NB:

(a) i.e. unemployed/have no other alternative income source

(b) Other push Entrepreneurship= "retrenched" + "Inadequate income from Other Sources" + "Unhappiness with previous word" + "Other reasons"

(c) Pull Entrepreneurship = "Inheritated/family tradition" + "I like the activity" + "I have the skills for this business" + "I have the equipment for this business" + "Activity brings high income" + "Small investment needed" SESE, 2005, questionnaire)

(d) Weighted shares: Author's computation. In Stata 11, when the Pearson chi-squared statistic is corrected for the survey design (H0: homogeneity of distributions between group 1 and group 2) it is converted into an F statistic.

*** significant at 1 percent; ${ }^{* *}$ significant at 5 percent; * significant at 10 percent.

\begin{tabular}{|c|c|c|c|}
\hline \multirow{3}{*}{ African and Colored } & \multirow{2}{*}{$\begin{array}{c}\text { Total } \\
\text { Homogeneity } \\
\text { of Men and Women } \\
\text { distribution by race } i\end{array}$} & MEN & WOMEN \\
\hline & & \multicolumn{2}{|c|}{$\begin{array}{c}\text { Homogeneity } \\
\text { of race } i \text { and White } \\
\text { distribution }\end{array}$} \\
\hline & $14.43^{* * *}$ & & \\
\hline White and Other & $4.87^{* *}$ & & \\
\hline Indian and Asian & 0.39 & & \\
\hline Total & $10.69^{* * *}$ & 0.93 & $19.38^{* * *}$ \\
\hline
\end{tabular}


From these results, three hypotheses, two of which are closely connected, arise immediately:

Hypothesis 3a: If women are more likely to be "push" entrepreneurs, their earnings differentials between employment and entrepreneurship should be low or inexistent.

Hypothesis 3b: If men are more likely to be "pull" entrepreneurs, their earnings differentials between employment and entrepreneurship should be important and in favor of entrepreneurship.

Table 5: Wage-entrepreneurship annual average earnings index by sector, human capital and gender in the informal sector (LSF, SESE, 2005)

\begin{tabular}{|c|c|c|c|}
\hline & Representativity Index & (a) & (b) \\
\hline \multirow{8}{*}{ 惫 } & No Education & $1.400 *$ & 0.694 \\
\hline & Primary Education & $1.336^{*}$ & 1.346 \\
\hline & Secondary Education & $1.378^{* * *}$ & $1.428^{*}$ \\
\hline & University or Other Superior Education & 1.486 & $2.101 *$ \\
\hline & African and Colored & $1.512 * * *$ & $1.558^{*}$ \\
\hline & White and Others & 1.049 & 1.885 \\
\hline & Indianand Asian & $2.230 *$ & 3.183 \\
\hline & Total & $1.610^{* * *}$ & $1.791 * *$ \\
\hline \multirow{8}{*}{$\begin{array}{l}\text { Z } \\
\text { 至 } \\
\text { 方 }\end{array}$} & No education & 1.001 & $1.802 *$ \\
\hline & Primary Education & 1.058 & 0.918 \\
\hline & Secondary Education & $1.270^{* *}$ & $1.546^{* *}$ \\
\hline & University or Other Superior Education & 0.502 & 1.769 \\
\hline & African and Colored & 1.106 & $1.482 * *$ \\
\hline & White and Others & 0.886 & 0.978 \\
\hline & Indian and Asian & 0.844 & $2.383 * * *$ \\
\hline & Total & 1.123 & $1.605^{* * *}$ \\
\hline \multicolumn{2}{|c|}{ TOTAL } & $1.381 * * *$ & $1.837^{* * *}$ \\
\hline
\end{tabular}

NB:
(a) $R I_{i j / k}=$
Informal Self-Employed revenues of race $i$, gender $j$ (Human capital $k$ ) Informal Wage - Earnings of race $i$, gender $j$ (Human capital $k$ )
(b) $R I_{i j / k}=$ Pull Self-Employed revenues of race $i$, gender $j$ (Human capital $k$ ) Push Self-Employed revenues of race $i$, gender $j$ (Human capital $k$ ) computed only on the SESE observations;
(c) Author's computations on weighted average: adjusted Wald test of mean comparison: *** significant at 1 percent; ${ }^{* *}$ significant at 5 percent; ${ }^{*}$ significant at 10 percent.


In order to test these two connected hypotheses, average revenues obtained from wage earning activities and from entrepreneurship in the informal sector have been measured. A wage earning advantage index was then calculated. Table 5 (column(a)) shows that, men's informal entrepreneurial incomes are 61 percent higher than those obtained in the informal employment status whereas informal self-employed women earn revenues that are only 12 percent higher than those of their employed counterparts. Moreover, the Wald tests indicate that the means of revenues are significantly different at a 1 percent level for men but are insignificant for women at a 10 percent level. At first sight, this result seems to validate the two hypotheses $3 \mathrm{a}$ and $3 \mathrm{~b}$. Moreover, when race is taken into account, except for the White population, the two hypotheses stay valid. According to the Pearson mean comparison test, regardless of race, women's informal self-employed revenues are equivalent to those of their informal employed counterparts. As for men, contrary to White self-employed, Non-White informal entrepreneurs earn higher revenues than their employed counterparts.

Yet, the problem of measuring average revenues on the employment and self-employment populations is that these populations may not be identical since they may have different labor performing characteristics which can determine their level of revenues. In Amit and al. $(1990,1995)$ and Evans and Leighton (1989), people who switched to self-employment had low labor performance during their wage earning activities and thus received small wage earnings. In that configuration, entrepreneurs, on average, might receive lower revenues than those of their wage earning counterparts, but higher revenues than those they used to gain through their working activities. Moreover, according to Hamilton (2000), Evans and Leighton (1989), and Blanchflower and Oswald (1995), entrepreneurs may decide to create their enterprise for the non-pecuniary benefits that entrepreneurship provides such as autonomy or being your own boss. Therefore, regardless of their performance, entrepreneurs might receive lower revenues than their employed counterparts. On the other hand, in Groysberg and al. (2007), people who were high performers in their employment activities and thus obtained the highest wages became entrepreneurs. In that situation, the average revenues of entrepreneurs should be higher than the ones of wage earners. According to Table 5 (column (a)), when education is taken into account $^{14}$, the gender disparity observed above globally remains. Regardless of the level of education, informal male entrepreneurs earn average revenues which are significantly higher than those of their employed counterpart

14 Education has been considered as a proxy for people's economic observable performance. 
while female entrepreneurs, on average, earn revenues which are not significantly different from those of their employed counterparts ${ }^{15}$. If education was the unique element of segmentation between "push" and "pull" entrepreneurs, we should have observed that regardless of gender, earnings differentials between the two occupations would have been important for highly educated people and small for low educated people. Therefore, our results suggest that, even when women are "pull" entrepreneurs, they are less responsive to earnings differentials between employment and self-employment than men. Probably, women are more sensitive than men to non pecuniary benefits provided by entrepreneurship.

Hypothesis 4: Since earnings grow with the level of education, "pull" entrepreneurial earnings should be higher than "push" entrepreneurial earnings.

Finally, it is interesting to notice that "pull" self-employed men and women earn revenues 79 percent and 61 percent higher than their pushed counterparts (see Table 5: column (b)). These differences are statistically significant at a 1 percent level. It is notably the case of African-Colored male and female entrepreneurs as well as the case of Indian-Asian women. Conversely, whereas men's earnings disparities between "pull" and "push" entrepreneurships increase with the level of education, women's earnings disparities exhibit an inverse U-shape. However, some earnings indexes are not significant even at a 10 percent level.

To summarize, the South African informal entrepreneurship seems to be characterized by a sort of gender dualism. Indeed, for men, entrepreneurship seems to have been chosen as it makes possible for male entrepreneurs to obtain higher annual revenues. "Pull" motivations have a positive significant impact on men's self-employment earnings and their positive influence on earnings grows with education. Conversely, regardless of education and race, female entrepreneurs do not earn higher revenues than their employed counterparts. Moreover, globally, "pull" motivations increase women's earnings, but their impact does not systematically grow with women's level of education. To conclude, gender seems to have significant effects on the nature of entrepreneurship, probably by playing a role on the decision to create an enterprise. Since capital accumulation as well as access to credit are also important determinants of firm creation, these determinants must be central to the explanation of these entrepreneurship gender disparities. Therefore, men and women's start-up capital will be questioned in the following sections.

15 Highly educated men and secondary educated women differ from the rest of men and women's entrepreneurial population. 


\section{MEN AND WOMEN'S PERSONAL ASSET ACCUMULATION AND ACCESS TO LOANS}

Launching a business often requires finding the necessary funds before any decision of registration and of production. Indeed, the lack of access to financial funds can be a major obstacle to entrepreneurship (Evans and Jovanovic, 1989, Blanchflower and Oswald 1998). Due to problems of moral hazard and adverse selection, capital markets do not provide enough capital to entrepreneurs (Knight1921). This implies that entrepreneurs must bear all the risks i.e. those related to the implementations of innovation and as well those related to funding. because of this situation, entrepreneurial activity cannot be the result of the decision of less risk-averse people (Kihlstrom and Laffont 1979). The 'Knightian' entrepreneurship approach thus conflicts with the 'Schumpeterian' vision which, on the contrary, distinguishes the entrepreneur who identifies and chooses between different opportunities, from the capitalists who run the risk for him(her) in the capital market. Consequently, entrepreneurial activity rarely is an option for young workers since people who wish to enter into entrepreneurial activity will have to spend a long period of time in the wage-earning activity in order to accumulate the compulsory savings that will constitute their initial personal assets. Many studies have actually shown that personal savings, loans and donations from friends and family play a critical role in the implementation of entrepreneurial activity (Evans and Jovanovic 1989, Holtz-Eakin 1994, 1994b). They are the most important sources of capital for the newly established firms. Once the company is established, the role of personal savings decreases as institutional investors perceive less risk and, all things being equal, are more inclined to provide capital (Stiglitz and Weiss 1981). These different studies suggest that newly created firms are constrained and that the amount of their initial capital is limited by the entrepreneurs' personal contributions. Therefore, the wage earning period becomes a prerequisite for savings since the revenues obtained during the wage earning interlude allow the future entrepreneur when (s)he cannot benefit from inheritance or family donations to accumulate sufficient savings or personal contributions necessary to his(her) firm creation.

In the case of "push" entrepreneurship, this step still stays fundamental since the wage-earnings obtained from the labor world make it possible to accumulate sufficient savings or personal contributions for the new business start-up. However, low wages, long period of unemployment, bad quality job, may have numerous effects on the entrepreneurial decision. First, when it becomes urging to launch a business to offset unemployment, future entrepreneurs may frequently forego the setting up of start-up capital or move to 
sectors where the need for seed capital is low or inexistent. Second, with the same marginal propensity to save, they may delay their entry into the business world although they may be urged to enter due to their unemployment situation. Finally, they may try to offset the impossibility of accruing savings by finding alternatives sources of funding i.e. selling assets, obtaining funds from the participation of a ROSCAS 16 , requesting gifts from family members, relatives, and friends. All this suggests that the amount of "push" entrepreneurs' personal assets may be lower and more diversified than those of their "pull" counterparts. Yet, probably, the most important aspect about "push" and "pull" entrepreneurships, is that, contrary to "pull" entrepreneurs, "push" entrepreneurs may not have accumulated savings for the purpose of starting a business which may imply that the amount and the sources of personal assets may be inadequate for launching a business. All these difficulties in the savings accumulation in the labor market will, of course, affect the entrepreneur's loan applications. Firstly, like in Kon and Storey, (2003) and Marlow and Carter, (2006), because of weak capital contribution, "push" entrepreneurs may be more likely to decide, despite strong financial needs, not to apply for loans because they anticipate that their loan application will be rejected by financial institutions. Indeed, because of the inexistence or the weakness of their personal assets, banks may be less inclined to grant them loans. In addition, loan conditions i.e. the amount, the terms, the interest rates, and the insurance cost may be less advantageous when the entrepreneur's pledges and mortgages cannot offset the risk of bankruptcy and default of payment perceived by lenders.

In particular, many studies have demonstrated that women may be more affected by access to financial resources than men do. According to Brush (1992), constituting the start-up capital is one of the biggest constraints of women's firm creation. They generally lack of important prerequisites, among which human capital, to obtain the success of their firm (Lerner, et al. 1997). Notably, women find it more difficult than men to access to external resources, which lead them to start with low and insufficient start-up capital (Sabarwal and Terrell 2008, Coleman 2007, Carter and Allen 1997, Carter and Van Auken 2007). To fund their business, women must therefore take on more personal debt to constitute their start-up capital (Heffernan 2007). These gender resource gaps on human capital and financial resources may be prominently explained by gender differences in motivations and expectations on entrepreneurial career. Yet, behind women's lower revenues and lower start-up capital, the role of discriminatory practices can be prevalent.

16 i.e. Rotating Savings and Credit Association. 
Many studies have shown that gender like race or ethnicity is an important determinant of loan demand, and of access to credit in terms of denial and loan conditions (Muravyev et al. 2009, Minitti and Narbonne 2007, Robichaud et al. 2007, Rodney et al. 2006, Menzies et al. 2006, Blanchard et al. 2005, Aaronson et al. 2000, Fafchamps 2000, Blanchflower et al. 1998, 2003, Bates 1991, 1997, Cavalluzzo and Cavalluzzo 1998). Upstream discriminations in the labor market like downstream discriminations in the capital market may affect the way women accumulate their savings and therefore banks' rules for awarding credits (Coate and Tennyson 1982). The fact that women are more "pushed" into than "pulled" in entrepreneurship can be the consequence of discriminatory practices on the labor market since discrimination can modify women's perceptions on entrepreneurship and on access to job and therefore alter their effort in human and financial resources accumulation. Consequently, since women are more "push" entrepreneurs than men, they should earn lower revenues and obtain lower amounts of personal assets and access to credit. The consequence of lower access to internal and external financial resources should push women to diversify their resources? Yet, diversification may be also the consequence of cultural and family pressures. According to Khavul et al. (2009), in particular in the informal sector where traditional laws are applied, in the name of solidarity, all members of a family may have a claim on the proceeds of the enterprise created by the entrepreneur. These strong pressures from extended family ties may push men and especially women to find business partners from outside the family and to diversify the sources of their assets and loans in order to obtain higher independence and freedom in their business management. I assume the following assumptions (see Figure 2).

Hypothesis 5a: Employed women earn lower revenues than their male counterparts.

Table 6 shows that, regardless of sector, race, and human capital, South African employed women globally earn lower revenues than their male counterparts. If these differences may be due to endowment disparities other than human capital, part of these differences may be the consequences of labor market discriminations against women (Appleton et al. 1999, Anderson and Shapiro 1996, Chamberlain et al. 2002, Coate and Tennyson 1992, Rospabé 2001).

Hypothesis 5b: Since women are less educated, more "push" entrepreneurs, and may be more constrained by access to credit then men, women's entrepreneurial earnings should be lower than those of their male counterparts. 
Regardless of motivations (and even sectors), female entrepreneurs generally earn lower revenues than their male counterparts. When motivations are taken into account, regardless of human capital, "pull" and "push" male entrepreneurs obtain higher revenues than their female counterparts. Moreover, these gender differences are observed essentially in the African and Colored group. There are, indeed, no significant differences between White and Indian-Asian men and women regardless of their motivations. These differences may be related to gaps in firm performance: lower profits allow lower revenues. These performance discrepancies may be due to human capital disparities, to the difficult access to financial resources as well as to banks and consumers' discriminations (Blanchard et al. 2005, Borjas and Bronars 1989, Fafchamps 2000, Fairlie and Meyer 1996).

Table 6: Gender annual average earnings index by human capital and race (LSF, SESE, 2005)

\begin{tabular}{|c|c|c|c|c|c|c|c|}
\hline & \multicolumn{2}{|c|}{ SELF-EMPLOYED } & \multicolumn{2}{|c|}{ EMPLOYED } & \multicolumn{3}{|c|}{ SESE } \\
\hline & INFORMAL & FORMAL & INFORMAL & FORMAL & TOTAL & Push & Pull \\
\hline No Education & $2.190 * * *$ & 1.986 & 1.566 & $1.479 * * *$ & $2.359^{* * *}$ & $2.772 * * *$ & 1.067 \\
\hline Primary Education & 1.630 ** & 1.671 & $1.291 * * *$ & $1.457^{* * *}$ & $1.822 * * *$ & $1.668^{*}$ & $2.446^{* * *}$ \\
\hline Secondary Education & $1.671^{* * *}$ & $1.371 *$ & $1.540 * * *$ & $1.228 * * *$ & $1.804^{* * *}$ & $1.850 * * *$ & $1.709^{* * *}$ \\
\hline $\begin{array}{l}\text { University or Other } \\
\text { Superior Education }\end{array}$ & $2.423 * * *$ & $1.923 * * *$ & 0.819 & 1.200 & $2.665^{* * *}$ & $2.247^{* *}$ & $2.668^{* *}$ \\
\hline African and Colored & $1.991 * * *$ & 0.932 & $1.456^{* * *}$ & 0.877 & $2.058^{* * *}$ & $1.995^{* * *}$ & $2.097 * * *$ \\
\hline White and Others & 1.168 & $1.754^{* * *}$ & 0.986 & $1.530 * * *$ & 1.608 & 1.169 & 2.252 \\
\hline Indian and Asian & $3.354 * *$ & 0.934 & 1.269 & $1.451 * * *$ & $3.823 *$ & 2.743 & 3.663 \\
\hline TOTAL & $1.980^{* * *}$ & $1.534^{* * *}$ & $1.382 * * *$ & 1.015 & $2.150 * * *$ & $2.017^{* * *}$ & $2.251^{* * *}$ \\
\hline
\end{tabular}

NB:

(a) Author's computation on weighted average (b) Gender earning index i.e. $M / F=\frac{\text { Men's }(\text { In)formal revenues }}{\text { Women's }(\text { In)formal revenues }}$ with adjusted Wald test of
mean comparison:

(c) ${ }^{* * *}$ significant at 1 percent; ${ }^{* *}$ significant at 5 percent; * significant at 10 percent.

Hypothesis 6a: Self-employed women should have lower personal assets than their male counterparts. 
Like in Verheul and Thurik (2001) and Carter and Allen (1997), women's average personal assets are actually lower than those of men. In the informal sector, men's personal contributions are, typically, around 6 times higher than those of women (see Table 7). Personal assets account for 81 percent of men's and 60 percent of women's start-up capital. Regardless of race, mean comparison tests indicate that these gender disparities are very significant (see Table 7: note (f)). This lower amount of personal assets may be due to lower revenues in the labor market as well as a more difficult access to remunerated savings. Yet, cultural pressures on women on women may also explain these disparities in behavior. In South Africa like in many East African countries, the business created by a woman traditionally belongs to her husband or family. It is notably true in the informal sector where official property rights are not applied. Women may be expropriated from their business insofar as some family members may take her business revenues, assets or stocks (Khavul et al. 2009). This non-protection of women's property rights may explain that women may have less incentives than men to accumulate personal assets. However, there is no question in the SESE that would make it possible to analyze this cultural aspect.

Hypothesis 6b: "Push" self-employed should have lower personal assets than their "pull" counterparts.

According to Table 717, regardless of gender, "pull" entrepreneurs have higher average personal assets then their "push" counterparts ${ }^{18}$. Again, motivations play a significant role on men's and women's personal assets. If we connect these results with hypothesis 5a, contrary to what Evans and Jovanovic assume in their model (1989), personal asset is not exogenous to the wages received in the previous period. This implies that obtaining systematically lower wages than those of male or "pull" entrepreneurs leads female or "push" entrepreneurs to greater difficulties in accumulating savings, and therefore to smaller personal assets than those of their male or "pull" counterparts.

17 Average amounts are calculated on the SESE population who needed capital to start their business. Within this population, some people have not succeeded in obtaining personal assets as well as loans. In Tables 8 and 9, only the population who has obtained personal assets or loans is taken into account. This explains why the amounts are larger than in Table 7.

18 Yet, when race is distinguished, these differences are significant only for African-Colored men. For the other categories, the differences are rarely significant, probably because of insufficient observations. 43 percent of white entrepreneurs had no need for capital assets, and 43 percent had only personal assets in contrast to respectively 24 percent and 52 percent of African-Colored entrepreneurs. Indian-Asian women, as indicated previously, are under-represented in the SESE compared to the LFS informal self-employed population, and clearly must be analyzed with caution. 


\begin{tabular}{|c|c|c|c|c|c|c|c|c|c|}
\hline 胥 & $\begin{array}{l}\text { ô } \\
\text { in } \\
\text { in }\end{array}$ & 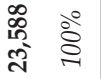 & 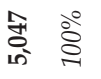 & 옹 : & 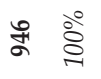 & 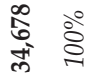 & 命 & 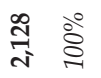 & 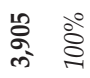 \\
\hline 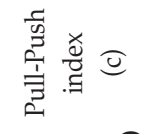 & $\begin{array}{l}\text { 鬲 } \\
\text { 员 } \\
\infty\end{array}$ & $\underset{\text { Ḣ }}{\stackrel{H}{H}}$ & $\begin{array}{l}\text { ָे } \\
\text { ָे } \\
\text { ָे }\end{array}$ & 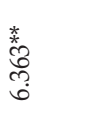 & مै & 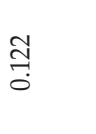 & 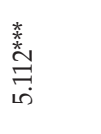 & 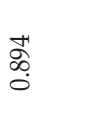 & $\begin{array}{l}\frac{L}{\sigma} \\
\stackrel{\sim}{N}\end{array}$ \\
\hline 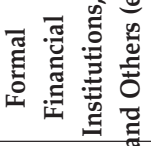 & ત్రి ঐ̊ & $\begin{array}{l}\stackrel{\circ}{\circ} \\
\stackrel{2}{人}\end{array}$ & 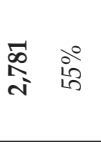 & 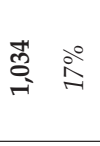 & జి & 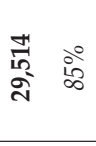 & సิ ஃ̊ำ & 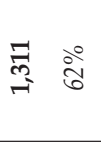 & $\stackrel{\infty}{\stackrel{\infty}{二}} \stackrel{8}{=}$ \\
\hline 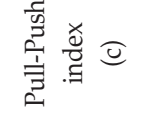 & 会 & $\begin{array}{l}8 \\
0 \\
0\end{array}$ & $\begin{array}{l}8 \\
0\end{array}$ & 荬 & $\begin{array}{l}\text { ले } \\
\text { ले }\end{array}$ & $\begin{array}{l}8 \\
0 \\
0\end{array}$ & 艺 & $\stackrel{8}{\circledR}$ & ڤ్ \\
\hline 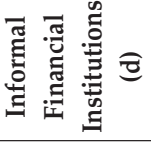 & $\stackrel{\text { ڤి }}{\circ}$ & 迅 ஓे & :ి $\stackrel{\circ}{\sim}$ & लే ঐ̊ & ले & ब्रे & - & L & $\stackrel{\circ}{\sim}$ \\
\hline 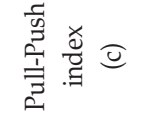 & 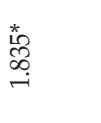 & 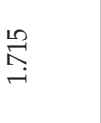 & $\begin{array}{l}\widetilde{\Xi} \\
\text { เे }\end{array}$ & ڤै & 咅 & $\begin{array}{l}2 \\
\text { ô } \\
\text { i }\end{array}$ & §̊ & 党 & 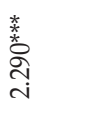 \\
\hline 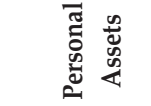 & \begin{tabular}{l}
\multirow{d}{*}{} \\
$\stackrel{+}{*}$
\end{tabular} & $\begin{array}{l}\text { के } \\
\text { î } \\
\text { in }\end{array}$ & 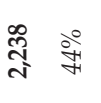 & \begin{tabular}{ll}
$\vec{\infty}$ & $\stackrel{0}{\infty}$ \\
\multirow{+}{\infty}{} & $\stackrel{5}{\infty}$
\end{tabular} & 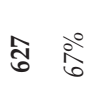 & 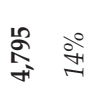 & तี & N & 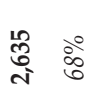 \\
\hline & త 2 & త 2 & త 2 & త 2 & త 2 & త 2 & త 2 & $\approx$ & అ \\
\hline & 㽕 & 苞 & 訇 & 总 & 泀 & 总 & 旁 & 节 & 总 \\
\hline \multirow[t]{2}{*}{$\underset{\beth}{\mathscr{U}}$} & 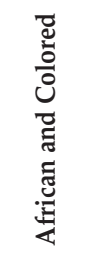 & 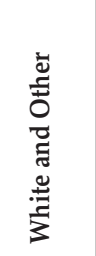 & 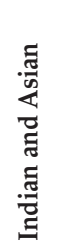 & 吾 & 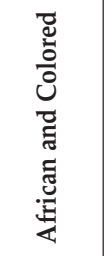 & 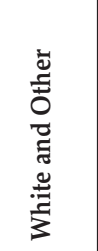 & 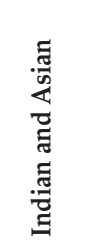 & 苛 & \multirow[t]{2}{*}{ 岕 } \\
\hline & \multicolumn{4}{|c|}{ NaW } & \multicolumn{4}{|c|}{ NGWOM } & \\
\hline
\end{tabular}


NB:

(a) Author's computations: in bold, weighted means: Since firms were created at different periods, the amounts for each enterprise were actualized based on the year 2005. The STATA SA Consumer Index Price was used to deflate the different amounts according to the business age. These figures take into account the entrepreneurial population which needed support or not. Therefore, for some entrepreneurs, start-up capital may be null. The average start-up capital (Total) is composed of the average amount of personal assets and the average amounts of loans from informal and formal financial institutions.

(b) The start-up capital distribution of the entrepreneurial population by race and gender.

(c) The Pull-Push amount index is computed the following way:

$$
I R_{\text {pull/push }}=\frac{\text { Average amount of pulled entrepreneur of gender } j \text { and race } k}{\text { Average amount of pushed entrepreneur of gender } j \text { and race } k}
$$

with the adjusted Wald test of Push-Pull mean comparison by race and gender: ${ }^{* * *}$ significant at 1 percent; ${ }^{* *}$ significant at 5 percent; * significant at 10 percent

(d) i.e. stokvels or any other cooperative or collective arrangements.

(e) Formal financial institutions, and others = see Table 9.

(g) Adjusted Wald test of gender/racial mean comparison by race: ${ }^{* *}$ significant at 1 percent; ** significant at 5 percent; * significant at 10 percent

\begin{tabular}{|l|c|c|c|c|}
\hline AMOUNT & $\begin{array}{c}\text { Personal } \\
\text { Assets }\end{array}$ & $\begin{array}{c}\text { Informal } \\
\text { Financial } \\
\text { Institutions }\end{array}$ & $\begin{array}{c}\text { Formal Financial } \\
\text { Institutions, } \\
\text { and Others }\end{array}$ & $\begin{array}{c}\text { Start-up } \\
\text { capital }\end{array}$ \\
\hline African and Colored & $28.53^{* * *}$ & 0.97 & 1.80 & $27.49^{* * *}$ \\
\hline White and Other & $2.95^{*}$ & 0.20 & 1.01 & 0.17 \\
\hline Indian and Asian & $3.31^{*}$ & 0.90 & 0.92 & 2.86 \\
\hline Total & $26.35^{* * *}$ & 1.43 & 0.10 & $8.69^{* * *}$ \\
\hline
\end{tabular}

(h) Adjusted Wald test of racial mean comparison by gender: ${ }^{* * *}$ significant at $1 \%$; ${ }^{* *}$ significant at $5 \%$; ${ }^{*}$ significant at $10 \%$

\begin{tabular}{|c|c|c|c|c|c|}
\hline & DUNT & $\begin{array}{c}\text { Personal } \\
\text { Assets }\end{array}$ & $\begin{array}{l}\text { Informal } \\
\text { Financial }\end{array}$ & $\begin{array}{c}\text { Formal Financial } \\
\text { Institutions, }\end{array}$ & $\begin{array}{c}\text { Start-up } \\
\text { capital }\end{array}$ \\
\hline & African-Colored /White-Others & $5.68^{* *}$ & 0.72 & $3.42^{*}$ & 6.20 \\
\hline 昰 & African-Colored /Indian-Asian & $3.04^{*}$ & 0.95 & 0.68 & 0.00 \\
\hline & Indian-Asian /White-Others & $7.12^{* * *}$ & 0.91 & 1.04 & $5.06^{* *}$ \\
\hline & African-Colored /White-Others & 2.68 & 0.77 & 2.00 & 2.13 \\
\hline$\sum_{0}^{\omega}$ & African-Colored /Indian-Asian & $16.34^{* * *}$ & $11.91^{* * *}$ & 0.30 & $10.97^{* * *}$ \\
\hline 3 & Indian-Asian /White-Others & $3.25^{*}$ & 0.93 & 2.01 & 2.20 \\
\hline
\end{tabular}


Hypothesis 7: Women's sources of personal assets are more diversified than those of men

Both men and women's personal assets mainly stem from past work incomes (see Table 8). Yet, 74 percent of men compared to 50 percent of women have personal assets which originate from past earnings saved during their previous labor or business period. This can probably be explained by the weakness of women's labor earnings and by the fact that they are more "push" than "pull" entrepreneurs. Yet, the fact that women's property rights are less respected in the informal sector than in the formal sector may explain that women have less incentives than men to accrue savings (Khavul et al. 2009) This gender disparity, however, must be tempered by the fact that while 11 percent of men's personal contributions stem from stokvels ${ }^{19}$ and other sources of savings, this rate reaches 32 percent for women. Thus, 85 percent of men and 82 percent of women have personal assets which result from total personal savings which group savings from labor incomes, stokvels and other sources of savings (i.e. family, friend's donations etc.). Yet, there are strong significant racial differences. 87 percent of Indian-Asian men and 75 percent of African-Colored men have accumulated their personal assets from past-work revenues compared to 56 percent of their White counterparts. Conversely, regardless of race, only around 50 percent of women rely on past-work revenues to accumulate personal assets. Non-White female entrepreneurs, however, are more inclined to use informal savings than their White counterparts since more than 30 percent of African-Colored and Indian-Asian women's personal assets come from money paid out from stokvels, and other sources of savings.

To summarize, in the informal sector, the fund-raising sources of men and women's personal assets are essentially accumulated from the labor and business world earnings. Yet, women who are more likely to be "push" entrepreneurs or discriminated-against in the labor market obtain lower personal assets and must rely more heavily than men do on stokvel pay out or on relatives and friends' saving. This may be explained by the fact that women have lower wages and lower access to jobs than men do, and must therefore, diversify their fund resources in order to successfully accumulate a sufficient amount of seed capital. Despite, this diversification, women's personal assets amounts, regardless of their source, are significantly lower than those of their male counterparts.

19 Stokvel is the South African term for rotating credit unions. It is an informal financial institution of credit and its functioning is the same as a rotating credit union. 
Table 8: Distribution of the main sources of entrepreneurs' personal assets (SESE, 2005)

\begin{tabular}{|c|c|c|c|c|c|c|}
\hline \multicolumn{7}{|c|}{ Savings from } \\
\hline & RACE & $\begin{array}{c}\text { Work } \\
\text { revenues } \\
\text { (a) }\end{array}$ & $\begin{array}{l}\text { Assets } \\
\text { revenues } \\
\text { (b) }\end{array}$ & $\begin{array}{l}\text { Non-Work } \\
\text { revenues } \\
\text { (c) }\end{array}$ & $\begin{array}{c}\text { Stokvel } \\
\text { and Others } \\
\text { (d) }\end{array}$ & $\begin{array}{c}\text { Total } \\
\text { (e) }\end{array}$ \\
\hline \multirow{8}{*}{ 至 } & African and Colored & 6,297 & 5,804 & 25,150 & 8,654 & 7,713 \\
\hline & freq. $(f)$ & $75 \%$ & $8 \%$ & $6 \%$ & $10 \%$ & $100 \%$ \\
\hline & White and Others & 38,605 & 71,232 & 54,591 & 13,891 & 35,463 \\
\hline & freq. $(f)$ & $56 \%$ & $2 \%$ & $15 \%$ & $28 \%$ & $100 \%$ \\
\hline & Indian and Asian & 2,235 & 48,426 & & 242 & 3,873 \\
\hline & freq. $(f)$ & $87 \%$ & $4 \%$ & $0 \%$ & $9 \%$ & $100 \%$ \\
\hline & Total & 7,175 & 6,844 & 27,883 & 9,005 & 8,732 \\
\hline & freq. $(f)$ & $74 \%$ & $8 \%$ & $7 \%$ & $11 \%$ & $100 \%$ \\
\hline \multirow{10}{*}{$\sum_{\substack{z \\
0}}^{3}$} & African and Colored & 1,107 & 1,787 & 5,738 & 701 & 1,208 \\
\hline & freq. $(f)$ & $50 \%$ & $14 \%$ & $3 \%$ & $33 \%$ & $100 \%$ \\
\hline & White and Others & 2,857 & 16,860 & 18,160 & 9,000 & 9,132 \\
\hline & freq. $(f)$ & $49 \%$ & $36 \%$ & $3 \%$ & $12 \%$ & $100 \%$ \\
\hline & Indian and Asian & 769 & & & 155 & 474 \\
\hline & freq. $(f)$ & $50 \%$ & $14 \%$ & $3 \%$ & $32 \%$ & $100 \%$ \\
\hline & Total & 1,167 & 3,122 & 6,180 & 813 & 1,489 \\
\hline & freq. $(f)$ & $50 \%$ & $14 \%$ & $3 \%$ & $32 \%$ & $100 \%$ \\
\hline & TOTAL & 4,596 & 4,361 & 20,602 & 2,638 & 4,908 \\
\hline & freq. $(f)$ & $62 \%$ & $11 \%$ & $5 \%$ & $22 \%$ & $100 \%$ \\
\hline
\end{tabular}

NB:

(a) Work revenues: "previous/present wage employment" + "business revenues";

(b) Assets revenues = "sale of livestock/crops" + "sales of other assets" + "inheritance";

(c) Nonworking revenues = "pension from work" + "retirement/severance pay" + "a policy that matured";

(d) Stokvel savings and others = "money paid from a stokvel" + "other savings";

(e) Author's computation: in bold weighted averages estimated only on the entrepreneurial population who have declared having personal assets. This is why total (e) of Table 8 is different from the 'Total column' of Table 7. Since no direct information was given by the SESE on the amount of personal assets belonging to each source, the amounts of personal assets by source $j$ was estimated the following way for each observation $i$ :

Personal assets of source $_{j i}=\left(\right.$ Total Personal assets $\left.{ }_{i}\right) * D_{j i}$ with $D_{j i}=1$ when the main source of observation $i$ is $j ; 0$ otherwise. 
(f) The weighted shares $j$ account for the share of entrepreneurs who had used source $\mathrm{j}$ for the constitution of his(her) assets.

(g) Adjusted Wald test of gender mean comparison by race *** significant at 1 percent; ${ }^{* *}$ significant at 5 percent; * significant at 10 percent

\begin{tabular}{|l|c|c|c|c|c|}
\hline AMOUNT & $\begin{array}{c}\text { Work } \\
\text { revenues }\end{array}$ & $\begin{array}{c}\text { Assets } \\
\text { revenues }\end{array}$ & $\begin{array}{c}\text { Non Working } \\
\text { revenues }\end{array}$ & $\begin{array}{c}\text { Stokvel } \\
\text { savings } \\
\text { and others }\end{array}$ & Total \\
\hline African and Colored & $28.21^{* * *}$ & $6.20^{* *}$ & $3.13^{* * *}$ & 2.35 & $31.95^{* * *}$ \\
\hline White and Other & $7.00^{* *}$ & 0.64 & $17.03^{* * *}$ & 0.25 & $5.38^{* *}$ \\
\hline Indian and Asian & 1.25 & na & na & na & 2.60 \\
\hline Total & $24.53^{* * *}$ & 2.69 & $4.57^{* *}$ & $3.32^{*}$ & $28.78^{* * *}$ \\
\hline
\end{tabular}

(h) Adjusted Wald test of racial mean comparison by gender:

${ }^{* * *}$ significant at 1 percent; ${ }^{* *}$ significant at 5 percent; * significant at 10 percent

\begin{tabular}{|c|c|c|c|c|c|c|}
\hline & AMOUNT & $\begin{array}{c}\text { Work } \\
\text { revenues }\end{array}$ & $\begin{array}{c}\text { Assets } \\
\text { revenues }\end{array}$ & $\begin{array}{c}\text { Non Working } \\
\text { revenues }\end{array}$ & $\begin{array}{c}\text { Stokvel } \\
\text { savings } \\
\text { and others }\end{array}$ & Total \\
\hline \multirow{3}{*}{ 窐 } & $\begin{array}{l}\text { African-Colored/ } \\
\text { White-Others }\end{array}$ & $6.10^{* * *}$ & 1.45 & $5.08^{* *}$ & 0.25 & $8.47^{* * *}$ \\
\hline & $\begin{array}{l}\text { African-Colored/ } \\
\text { Indian-Asian }\end{array}$ & $8.73^{* *}$ & $976.69^{* * *}$ & na & 2.60 & $3.70^{*}$ \\
\hline & $\begin{array}{l}\text { Indian-Asian/ } \\
\text { White-Others }\end{array}$ & $\mathrm{Na}$ & na & na & na & na \\
\hline \multirow{3}{*}{$\begin{array}{l}\text { Z } \\
\sum_{0}^{1} \\
3 \\
3\end{array}$} & $\begin{array}{l}\text { African-Colored/ } \\
\text { White-Others }\end{array}$ & 2.03 & 2.21 & $12.91^{* * *}$ & $7.59^{* * *}$ & $3.14^{*}$ \\
\hline & $\begin{array}{l}\text { African-Colored/ } \\
\text { Indian-Asian }\end{array}$ & 0.87 & na & na & $9.14^{* * *}$ & $6.21^{* *}$ \\
\hline & $\begin{array}{l}\text { Indian Asian/ } \\
\text { White-Others }\end{array}$ & $\mathrm{Na}$ & na & na & na & na \\
\hline
\end{tabular}




\section{Figure 2: Entrepreneurial gender dualism and Access to savings and loans ${ }^{20}$}

Hypothesis 2: Self-employed women are more pushed entrepreneurs than men $+$

Women are less educated than men

$$
+
$$

gender (and racial) discriminations on the labor market

Hypothesis 7: men and women have different sources of personal assets

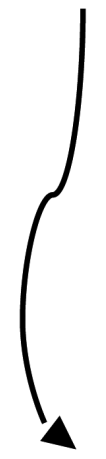

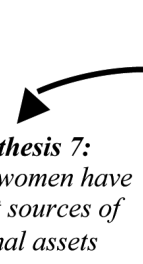

diff
Hypothesis 6a:

Women have lower personal savings than men

\section{Hypothesis 8:}

Men and Women have different sources of lonns

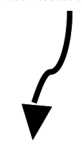

Hypothesis 5b:

Women have lower entrepreneurial revenues than men

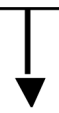

Hypothesis 5a:

in the labour market, women earn lower wages than men

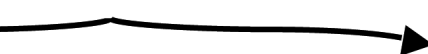

al

"Push" entrepreneurs have lower personal savings than their "pull" counterparts

\section{Hypothesis $9 a$}

Women have lower access to credit than men
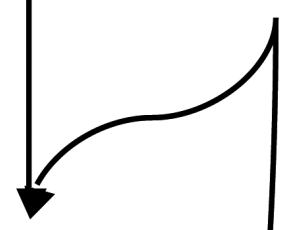

(hen

\section{Hypothesis $9 b$}

Hypothesis $9 \boldsymbol{b}$
" entrepreneurs have lower access to credit than their "pull" counterparts

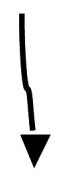

Hypothesis 4 (see Figure 1):

"Push" entrepreneurs have lower revenues than their "pull"

20 Hypotheses 7 and 8 could have been also tested between "pull" and "push" entrepreneurs. Yet when race, gender and the different types of start-up capital sources are taken into account, observations for some sub-categories are insufficient to elaborate pertinent means. Therefore, I have decided to concentrate only on global means of personal assets and access to loans. 
Hypothesis 8: Women's sources of loans are more diversified than those of men.

The distribution of loans according to their sources shows that, regardless of race and gender, loans from friends, relatives and business partners are the dominant sources of loans (see Table 9) since around 73 percent of men and women's loans originate from friends, relatives and business partners. As we have seen previously, not only friends and relatives are important contributors to entrepreneurs' personal assets, but they are also the main lenders of entrepreneurship. Family background and network seem to be important to compensate the weak access to loans from formal and informal financial institutions. This result indicates that strong barriers to loan access affect male and female entrepreneurs, regardless of race. Yet, there are gender disparities. Women must rely more on loans obtained from friends, relatives and business partners than men do since 74 percent of women's loans stem from friends, relatives and business partners compared to 72 percent of men's loans. Although women are more likely than men to be dominated by family members (Khavul et al. (2009), women seem to fail in the diversification of their access to loans ${ }^{21}$. In fact, like in Brophy (1989), Brush (1992), Kon and Storey (2003) and Marlow and Carter (2006), women are less likely than men to seek external sources of capital. If we only consider loans which do not originate from friends, relatives and business partners (i.e. freq 2 in Table 9), 72 percent of men's 'institutional' loans were obtained from for-profit formal and informal financial organizations compared to 48 percent of women's loans. On the other hand, respectively 15 percent and 36 percent of women's 'institutional' loans stem from non-profit organizations and from money lenders compared to 8 and 20 percent of men's. The way women obtain loans suggests that modern banking institutions and even informal microcredit organizations seem to adopt behaviors which compel women to seek their loans from money lenders or from financial non-profit institutions (NPO) which goal is to provide loans with preferential conditions and, for some institutions, to promote female entrepreneurship. These behaviors might not be systematically discriminatory since women are more likely to be "push" entrepreneurs and have lower education and personal assets than

21 This failure is also observed when women's business partner distribution is compared with that of men. 97 percent of women compared to 91 percent of men are single owners. Gender disparity is significant at a 1 percent level. However, when men and women have business partners, their distributions of their business partners between outside and inside household partners are equivalent at a 10 percent level of significance. These results suggest that women do not tend to diversify their sources of ownership more than would do men, contrary to what was suggested by Khavul et al. (2009). Yet, they rely less than men on business partners. 
Table 9: Distribution of loan sources by race and gender (SESE, 2005)

\begin{tabular}{|c|c|c|c|c|c|c|c|}
\hline & \multicolumn{4}{|c|}{ Formal financial institutions, and others (1) } & \multirow[b]{2}{*}{$\begin{array}{c}\text { Informal } \\
\text { financial } \\
\text { institutions } \\
\text { (2) }\end{array}$} & \multirow[b]{2}{*}{$\begin{array}{c}\text { Total loans } \\
\text { (3) }\end{array}$} \\
\hline & & $\begin{array}{l}\text { Friends, } \\
\text { relatives and } \\
\text { business } \\
\text { partners } \\
\text { (a) }\end{array}$ & $\begin{array}{l}\text { Commercial } \\
\text { banks } \\
\text { and credit } \\
\text { societies } \\
\text { (a) }\end{array}$ & $\begin{array}{l}\text { Business } \\
\text { associations, } \\
\text { NGOS } \\
\text { and NPOS } \\
\text { (a) }\end{array}$ & $\begin{array}{l}\text { Money } \\
\text { lenders } \\
\text { and } \\
\text { other } \\
\text { (a) }\end{array}$ & & \\
\hline \multirow{12}{*}{ 盖 } & African and Colored & 1,073 & 687 & 1,064 & 1,213 & 669 & 4,706 \\
\hline & freq. 1 & $74 \%$ & $5 \%$ & $2 \%$ & $6 \%$ & $13 \%$ & $100 \%$ \\
\hline & freq. 2 & & $\underline{21 \%}$ & $\underline{6 \%}$ & $\underline{23 \%}$ & $\underline{51 \%}$ & $\underline{100 \%}$ \\
\hline & White and Others & 16,083 & 38,797 & 0 & 0 & 6,087 & 60,967 \\
\hline & freq. 1 & $39 \%$ & $42 \%$ & $0 \%$ & $0 \%$ & $19 \%$ & $100 \%$ \\
\hline & freq. 2 & & $\underline{69 \%}$ & $\underline{0 \%}$ & $\underline{0 \%}$ & $\underline{31 \%}$ & $\underline{100 \%}$ \\
\hline & Indian-Asian & 954 & 0 & 14,869 & 0 & 161 & 15,984 \\
\hline & freq. 1 & $60 \%$ & $0 \%$ & $27 \%$ & $0 \%$ & $13 \%$ & $100 \%$ \\
\hline & freq. 2 & & $\underline{0 \%}$ & $\underline{67 \%}$ & $\underline{0 \%}$ & $\underline{33 \%}$ & $\underline{100 \%}$ \\
\hline & Total & 1,784 & 2,484 & 1,356 & 1,125 & 882 & 7,631 \\
\hline & freq. 1 & $72 \%$ & $7 \%$ & $2 \%$ & $6 \%$ & $13 \%$ & $28 \%$ \\
\hline & freq. 2 & & $\underline{25 \%}$ & $\underline{8 \%}$ & $\underline{20 \%}$ & $\underline{47 \%}$ & $\underline{100 \%}$ \\
\hline \multirow{11}{*}{$\begin{array}{l}\text { Zi } \\
\text { 至 } \\
3\end{array}$} & African and Colored & 865 & 109 & 105 & 125 & 138 & 1342 \\
\hline & freq. 1 & $74 \%$ & $2 \%$ & $4 \%$ & $9 \%$ & $10 \%$ & $100 \%$ \\
\hline & freq. 2 & & $\underline{8 \%}$ & $\underline{16 \%}$ & $36 \%$ & $39 \%$ & $100 \%$ \\
\hline & White and Others & 3825 & 168,187 & 0 & 20,676 & 2,408 & 195,096 \\
\hline & freq. 1 & $58 \%$ & $32 \%$ & $0 \%$ & $8 \%$ & $2 \%$ & $100 \%$ \\
\hline & freq. 2 & & $\underline{77 \%}$ & $\underline{0 \%}$ & $\underline{19 \%}$ & $\underline{4 \%}$ & $\underline{100 \%}$ \\
\hline & Indian and Asian & 755 & 0 & 0 & 0 & 0 & 755 \\
\hline & freq. 1 & $100 \%$ & $0 \%$ & $0 \%$ & $0 \%$ & $0 \%$ & $100 \%$ \\
\hline & Total & 932 & 3946 & 102 & 594 & 189 & 5,763 \\
\hline & freq. 1 & $74 \%$ & $3 \%$ & $4 \%$ & $9 \%$ & $10 \%$ & $100 \%$ \\
\hline & freq. 2 & & $\underline{11 \%}$ & $\underline{15 \%}$ & $\underline{36 \%}$ & $\underline{38 \%}$ & $\underline{100 \%}$ \\
\hline \multicolumn{2}{|c|}{ TOTAL } & 1,232 & 3,341 & 543 & 781 & 431 & 6,418 \\
\hline & freq. 1 & $73 \%$ & $4 \%$ & $3 \%$ & $8 \%$ & $11 \%$ & $100 \%$ \\
\hline & freq. 2 & & $16 \%$ & $\underline{12 \%}$ & $\underline{30 \%}$ & $\underline{42} \%$ & $\underline{100 \%}$ \\
\hline
\end{tabular}

NB:

(a) Author's computation. In bold, weighted average of borrowed amounts. Only the population who has borrowed money from any sources has been taken into account. Contrary to the rest of the population that had declared just one source of loans, 4 observations had de- 
clared two sources of loans. Yet the SESE gives a global amount for formal loans but not for each source of formal loans. Therefore the amounts of loans for each source of formal loans had to be estimated the following way for each observations $i$ :

Amount $_{i j}=\theta_{i j}\left(\right.$ Loan Amount of formal institutions ${ }_{i j}$ ) with $\theta_{i j}=\frac{n_{i j}}{N_{i}}$ where $n_{i j}$ number of sources of formal loans of types $j$ and $N_{i}$ the total number of sources of formal loans of observation $i$.

(b) Informal financial institutions i.e. Stokvels and informal collective agreement

(c) Adjusted Wald test of gender mean comparison by race:

*** significant at 1 percent; ${ }^{* *}$ significant at 5 percent; * significant at 10 percent

\begin{tabular}{|l|c|c|c|c|c|}
\hline & $\begin{array}{c}\text { Friends, relatives } \\
\text { and business } \\
\text { partners }\end{array}$ & $\begin{array}{c}\text { Commercial } \\
\text { banks and } \\
\text { credit societies }\end{array}$ & $\begin{array}{c}\text { Business } \\
\text { associations, } \\
\text { NGOS and NPOS }\end{array}$ & $\begin{array}{c}\text { Money } \\
\text { lenders } \\
\text { and other }\end{array}$ & $\begin{array}{c}\text { Informal } \\
\text { financial } \\
\text { institutions }\end{array}$ \\
\hline African and Colored & 0.52 & 1.08 & 1.12 & 1.08 & 0.60 \\
\hline White and Others & 0.96 & 0.83 & $\mathrm{Na}$ & 0.90 & 1.64 \\
\hline Indian and Asian & 0.07 & na & 1.17 & na & 0.82 \\
\hline Total & 1.18 & 0.15 & 1.93 & 0.23 & 0.91 \\
\hline
\end{tabular}

(d) Adjusted Wald test of racial mean comparison by gender:

*** significant at 1 percent; ${ }^{* *}$ significant at 5 percent; * significant at 10 percent

\begin{tabular}{|c|c|c|c|c|c|c|}
\hline & $\begin{array}{c}\text { Friends, relatives } \\
\text { and business } \\
\text { partners }\end{array}$ & $\begin{array}{c}\text { Commercial } \\
\text { banks and } \\
\text { credit societies }\end{array}$ & \begin{tabular}{|c|} 
Business \\
associations, \\
NGOS and NPOS
\end{tabular} & $\begin{array}{c}\text { Money } \\
\text { lenders } \\
\text { and other }\end{array}$ & $\begin{array}{c}\text { Informal } \\
\text { financial } \\
\text { institutions }\end{array}$ \\
\hline \multirow{3}{*}{ 要 } & $\begin{array}{l}\text { African-Colored/ } \\
\text { White }\end{array}$ & 1.53 & $3.45^{*}$ & 1.38 & 1.35 & 0.14 \\
\hline & $\begin{array}{l}\text { African-Colored/ } \\
\text { Indian-Asian }\end{array}$ & 0.03 & 1.55 & 1.18 & 1.35 & 0.30 \\
\hline & $\begin{array}{l}\text { Indian-Asian/ } \\
\text { White-Others }\end{array}$ & 1.57 & $3.59^{*}$ & 1.37 & na & 0.63 \\
\hline \multirow{3}{*}{$\begin{array}{l}z \\
\text { zy } \\
\text { co } \\
3\end{array}$} & $\begin{array}{l}\text { African-Colored/ } \\
\text { White }\end{array}$ & $3.09^{*}$ & 1.50 & $7.05^{* *}$ & 0.94 & $12.68^{* * *}$ \\
\hline & $\begin{array}{l}\text { African-Colored/ } \\
\text { Indian-Asian }\end{array}$ & 0.09 & $3.34^{*}$ & $7.05^{* *}$ & $13.21^{* * *}$ & $61.38^{* * *}$ \\
\hline & $\begin{array}{l}\text { Indian-Asian/ } \\
\text { White-Others }\end{array}$ & $3.21^{*}$ & 1.50 & na & 0.95 & 0.84 \\
\hline
\end{tabular}

(e) freq1: The weighted shares $j$ account for the share of loans which originate from source $j$ freq2: The weighted shares $j$ account for the share of loans which originate from source $j$ when the loan source of friends, relatives, family members and business partners is excluded.

(f) In columns (1) and (2), the average amounts were computed from the population who had obtained a loan. To obtain column (3), I have added the average amount of columns (1) and (2). The total amounts in Table 9 are higher than those observed in Table 7 since in Table 7, the amounts were calculated on all the population whereas in Table 9, only in the population that has obtained a loan. 
men. This means, though, that, regardless of race, women must rely more strongly than men on money lenders whose loans are generally more expensive than those of formal institutions because of higher interest payments.

Hypothesis 9a: Women's amounts of loans are less important than those of men

Yet, in terms of loan amounts, other conclusions can be drawn. According to previous Table 7 (see above), on average, men's loans amounts from informal financial institutions are around 3 times higher than those of women, while women's loans amounts from formal financial institutions are 27 percent higher than those of men. Globally, women's formal and informal loans amounts are 16 percent higher than those of men. Yet the Wald tests indicate that regardless of race, men's and women's amounts of formal as well as informal loans are not different at a 10 percent level of significance. Moreover, despite women's advantage in formal institutions, men's average start-up capital is around 3 times higher than that of women. The Wald test indicates that this gender difference in start-up capital is significant at a 1 percent level. Yet it is significantly observed only within the African-Colored population. In fact, significant gender well as racial disparities in start-up capital are essentially observed on the personal asset component. All these results may come from the fact that Table 7 includes all the SESE population. When only the population which has obtained a loan is taken into account (see Table 9), we observe that, except for commercial bank loans, men have higher amounts of loans than those of their female counterparts. In fact, women have acquired higher amounts of commercial bank loans than those of their male counterparts due to the White population. As for African-Colored as well as Indian-Asian women, they have received lower amounts than those of their male counterparts. The Wald tests indicate that regardless of race and sources of loans, men's and women's amount of loans are not significantly different at a 10 percent level. There seems to be no significant gender disparity in the amount of loans. Yet caution should be taken with this result since only 22 percent of men and 26 percent of women who needed financial support have declared a positive amount of loans.

Hypothesis 9b: Loan amounts of "push" entrepreneurs are less important than those of their "pull" counterparts.

According to Table 7, entrepreneurial motivations seem to influence the access to certain loans. For instance, White women who are, on average, more "pull" entrepreneurs than White men are granted higher amounts of 
commercial bank loans than those of their male counterparts. African-Colored "pull" female entrepreneurs obtain higher amounts of loans from formal institutions and relatives than their "push" counterparts. It is also the case for men, in general, who receive higher amounts from stokvels and from formal institutions when they are "pull" entrepreneurs. Therefore, "pull" entrepreneurship makes it possible to collect higher amounts of personal assets and therefore higher amounts of formal loans, which reduce their need for additional loans coming from informal institutions (Table 7). This is probably due to their educational and professional backgrounds as well as to their motivations for starting a business. Banks and formal financial institutions may see "pull" entrepreneurs as less risky than their "push" counterparts since they also provide higher amounts of personal assets.

\section{LIMITATIONS}

The previous results present some limitations. At first, my results are only pertinent for the informal sector since, unfortunately, the SESE only surveys entrepreneurs from the informal sector. Although I have tried to use as much as possible information from the LFS from which the SESE was extracted, it is not sufficient to infer conclusions for the formal sector. It would be interesting to have the same type of survey on formal entrepreneurs in order to see if this gender dualism is also observed in the formal sector and different from the informal sector and if women are more burned than men by access to credit and loans. Indeed, according to Khavul et al. (2009), in the informal sector, it is impossible for entrepreneurs, in particular women, to fully benefit from their ownership since, contrary to the formal sector, property rights are not clear, enforceable and standardized and traditional laws generally govern business conflict. Therefore, probably in the formal sector, this gender dualism might be not as strong as it can be in the informal sector.

Secondly, the SESE takes into account motives which are not gender oriented. If it is an advantage to have motives that can be common to men and women, especially if one wants to compare men and women's behaviors, it is, nevertheless, regretful that specific gender oriented motives like family motives were not introduced directly in the questionnaire. Probably, some women and even some men may not have answered the same way when family or motherhood motives are clearly formulated in the questionnaire. In addition, the SESE asked entrepreneurs what was the main motive for creating their business. It was not asked, for instance, to classify or gauge these motivations. It would be interesting to see if these results on motivations are 
not linked to the way motivations are measured.

Thirdly, it would have been interesting to analyze why self-employed men and women in South Africa have succeed or not in accumulating their savings and especially what were the institutions in which they accumulated their savings in. Unfortunately, although the SESE has important information on the lending institutions, it provides no information on the saving organizations and no questions were asked on the reasons for which people did not succeed in accruing saving. Moreover, it is impossible to determine whether people have tried to obtain these funds and what were the reasons for their failure to obtain them: Did they ask for loans and had a loan request refused? Did they ask for loans or try to save assets? Were they discouraged? The SESE only informs if people had a need for start-up capital or not. No information is also available concerning the loan conditions (interest rates, loan term).

Fourthly, when working on female entrepreneurship, it is important for researchers to have information on the family background and environment: Were some relatives of them entrepreneurs? Do they have children? Unfortunately, neither the LFS nor the SESE contrary to the GHS give such information. It is clear that family is a strong determinant of the nature of male and female entrepreneurship and would help to explain the differences of motivations between men and women but also their capacity to save sufficient personal assets and to access to loans.

Finally, if we want to better understand entrepreneurship and especially "push" entrepreneurship, we need to focalize our attention on discouraged job seekers. Among them, there are also discouraged enterprise creators. In fact little is known on why some people do not create or try to implement an enterprise even though they have no access to job. It would be interesting to see if women's constraints and motivations of not starting a necessity-based business differ from those of men. It would probably help the researchers to understand why, despite higher unemployment rates, women have not used entrepreneurship as a tool for survival. Unfortunately, LFS only questions unemployed people on the constraints they face during their job search and not during their attempt of creating a business

\section{CONCLUSION}

Despite some limitations, the results of this paper however suggest that contrary to what is observed in the rest of the African continent, informal entrepreneurship in South Africa seems to absorb or shelter just a small part of 
job seekers. South Africa has, indeed, the lowest entrepreneurial rate among the less developed countries which have participated to the 2006 Global Entrepreneurship Monitor (GEM) report (Bosma and Harding 2006). This is probably one of the most interesting aspects and particularities of South Africa compared to other African countries. This particularity may probably be due to the presence of gender dualism that affects women's access to saving and loans.

This paper has found evidence that, despite quite equivalent gender entrepreneurial rates, the South African informal sector is clearly characterized by a gender entrepreneurship dualism. Indeed, at first, contrary to Mitchell (2004), women and men differ considerably in terms of motivations. Like in Wagner (20005), female entrepreneurs are much more "push" entrepreneurs than their male counterparts. This can be explained by the fact that since women have the highest unemployment rates, they are more likely to choose entrepreneurship for necessity reasons. Yet, contrary to men and regardless of their motivations, women do not choose entrepreneurship because this occupation allows them to obtain higher revenues. However, regardless of gender, "pull" entrepreneurs obtain higher revenues than their "push" counterparts.

Secondly, due to the possible presence of gender (and also racial) discriminations, in the pre-entrepreneurial period, women earn lower wages than their male counterparts, which seems to reduce their capacity to accumulate the personal assets necessary for their start-up capital and for their loan approval. The fact that women have lower savings, however, may not only be due to lower previous earnings during the period of accumulation. Women might be more burdened by higher barriers to savings than men. Indeed, Dupas and Robinson (2009) have shown in the case of microentrepreneurs in Kenya ${ }^{22}$ that the majority of informal entrepreneurs, especially women, do not have access to a simple bank account and face strong saving constraints. Moreover, as demonstrated by Khavul et al. (2009), women are more burdened than men by traditional laws in the informal sector which reduce entrepreneur's property rights.

Thirdly, women seem to be obliged to resort to informal institutions and money lenders whose loan costs are higher than those of modern banking institutions. Moreover, except for the White population, women receive lower amounts of loans than those of their male counterparts regardless the sources of their loans. These results confirm what many studies including

22 It is interesting to notice that in Kenya, like South Africa, less than 10 percent of family enterprises are owned by women (see Bardasi et al. 2007). 
Brophy (1989) Brush (1992), Fay and Williams (1993), Carter and Allen (1997), Murayev et al. (2009) have observed in different countries. Yet, probably due to an insufficient number of observations, these gender disparities in loans amounts were not significant.

Finally, probably because of lower education, lower access to job which push women into entrepreneurship and lower access to savings and credit, female entrepreneurs earn lower revenues than their male counterparts.

All these results suggest that, in order to promote "pull" entrepreneurship rather than "push" entrepreneurship, public policies must reduce women's barriers to access to job. Notably, they must increase women's human capital prerequisites for access to job as well as for entrepreneurship and their efforts towards women must continue to be undertaken in order to reduce discrimination which may still be prevalent in the labor and capital markets. Yet, the reasons for gender (and racial) differences regarding personal asset accruing should also be brought to public authorities' attention. Indeed, probably, part of the entrepreneurial differences between gender (and race) are related to differences in personal asset accumulation. Asset accruing can be deterred by the fact that, in the informal sector, the entrepreneurs, in particular women, may not have access to remunerated savings. Moreover, they can be expropriated by family members or relatives. Although this may force men and women to diversify their sources of assets, notably by having business partners outside the family in order to gain independence and freedom in their management, this may also limit their incentives to accumulate personal savings. This implies that efforts toward the formalization of the economy should be strengthened as it is the only way to have clear, standardized and enforceable property rights.

\section{Reference}

Aaronson D., P.F. Huck and R. Townsend, 2001, "Small Business Access to Trade Credit: Some Evidence of Ethnic", Federal Reserve Bank of Chicago, issue May, pp. 423-451.

Acs Z.J., 2006, "How Is Entrepreneurship Good for Economic Growth", Innovations, Vol. 1, No. 1, pp. 97-107.

Appleton S., J. Hoddinot and P. Krishnan, 1999, "The Gender Wage Gap in Three African Countries", Economic Development and Cultural Change, Vol. 472, pp. 289312.

Amit R., L. Glosten and E. Muller, 1990, “Entrepreneurial Ability, Venture Investments, and Risk Sharing", Management Science, Vol. 36, pp. 1232-1245. 
Amit R. and E. Muller, 1994, "'Push' and 'Pull' Entrepreneurship", in W. Bygrave, et al. (eds.), Frontiers of Entrepreneurship Research, Babson College, Wellesley.

Amit R., E. Muller and I. Cockbur, 1995, "Opportunity Costs and Entrepreneurial Activity", Journal of Business Venturing, Vol. 102, pp. 95-106.

Anderson D. and D. Shapiro, 1996, "Racial Differences in Access to High-Paying Jobs and the Wage Gap between Black and White Women", Industrial and Labor Relation Reviews, Vol. 492, pp. 273-286.

Bardasi E., C.M. Blackden and J.C. Guzman, 2007, Chapter 14: Gender, Entrepreneurship and Competitiveness in Africa, in http://www.weforum.org/pdf/gcr/africa/1.4pdf.

Bates T., 1991, "Commercial Bank Financing of White and Black-Owned Small Business Startups", Quarterly Review of Economics and Business, Vol. 31, pp. 64-80.

Bates T., 1997, “Unequal Access: Financial Institution Lending to Black and WhiteOwned Small Business Startups", Journal of Urban Affairs, Vol. 19 (4), pp. 487-495.

Baum J.R. and E. Locke, 2004, "The Relationship of Entrepreneurial Traits, Skill, and Motivation to Subsequent Venture Growth", Journal of Applied Psychology, Vol. 4, pp. 587-598.

Benzing C., H.M Chu and C. McGee, 2007, "Ghanaian and Kenyan Enterprises: A Comparative Analysis of their Motivations, Success, Characteristics and Problems", Journal of Development Entrepreneurship, Vol. 12, No. 3, pp. 295-312.

Blanchflower D.G., B.L. Philip and D.J. Zimmerman, 2003, "Discrimination in the Small-Business Credit Market", Review of Economics and Statistics, Vol. 854, pp. 930-943.

Blanchflower D.G. and A.J. Oswald, 1998, "What Makes an Entrepreneur?", Journal of Labour Economics, Vol. 161, pp. 26-60.

Blanchard L., B. Zhao and J. Winger, 2005, "Do credit Market Barriers Exist for Minority and Woman Entrepreneurs?", Center for Policy Research Working Papers, No. 74, Center for Policy Research, Maxwell School, Syracuse University.

Bohla R., I. Verheul, I. Grilo and A.R. Thurik, 2006, Explaining Engagement Levels of Opportunity and Necessity Entrepreneurs, Research Report H200610, Zoetermeer: EIM Business and Policy Research.

Borjas G.J. and S.G. Bronars, 1989, "Consumer Discrimination and Self Employment", Journal of Political Economy, Vol. 973, pp. 581-605.

Bosma N. and R. Harding, 2006, “Global Entrepreneurship: GEM 2006 Summary Results", in Global Entrepreneurship Monitor Report, in http:/ /www.gemconsortium. org/docs/262/gem-2006-global-report.

Brophy D., 1989", Financing Women-Owned Entrepreneurial Firms", in Hagan O., C. Rivchun and D. Sexton, Women-Owned Businesses, New York: Praeger.

Brush C., 1992, "Research on Women Business Owners: Past Trends, a New Perspective and Future Directions", Entrepreneurship Theory and Practice, Vol. 16, No. 4, pp. 5-31. 
Businesswomen's Association of South Africa, South African Women in Corporate Leadership Census 2007, in http:/ / www.bwasa.co.za/Portals/4/docs/archive/Women_ in_Corporate_Leadership_Census_2007.pdf

Buttner E.H. and D.P. Moore, 1997, “Women's Organizational Exodus to Entrepreneurship: Self Reported Motivations and Correlates with Success", Journal of Small Business Management, Vol. 35, No. 1, pp. 34-46.

Carter N.M. and K.R. Allen, 1997, "Size Determinants of Women-Owned Business: Choice or Barriers to Resources?", Entrepreneurship and Regional Development, Vol. 9, pp. 211-220.

Carter N.M. and H. Van Auken, 2005, “Bootstrap Financing and Owners' Perceptions of Their Business Constraints and Opportunities", Entrepreneurship and Regional Development, Vol. 17, pp. 129-144.

Carter N.M., M. Williams, and P.D. Reynolds, 1997, “Discontinuance Among New Firms in Retail: The Influence of Initial Resources, Strategy, and Gender", Journal of Business Venturing, Vol. 12, No. 2, pp. 125-145.

Cavalluzzo K.S. and L.C. Cavalluzzo, 1998, "Market Structure and Discrimination: The Case of Small Business", Journal of Money, Credit and Banking, Vol. 30, No. 4, pp. 771-792.

Cavalluzzo K.S., L.C. Cavalluzzo, and J. Wolken, 2002, “Competition, Small Business Financing, and Discrimination: Evidence from a Survey", Journal of Business, Vol. 75, No. 4, pp. 641-680.

Chamberlain D. and S. Van der Berg, 2002, "Earnings Functions, Labour Market Discrimination and Quality of Education in South Africa", Stellenbosch Economic Working Papers 2/2002.

Coate S. and S. Tennyson, 1992, "Labour Market Discrimination, Imperfect Information and Self employment", Oxford Economic Papers, New Series, Vol. 44, No. 2, pp. 272-288.

Coleman S., 2007, "The Role of Human and Financial Capital in the Profitability and Growth of Women-Owned Small Firms", Journal of Small Business Management, Vol. 45, No. 3, pp. 303-319.

Coleman S., 2000, "Access to Capital and Terms of Credit: a Comparison of Men- and Women-Owned Small Businesses", Journal of Small Business Management, Vol. 38, No. 3, pp. 37-52.

Davidsson P. and B. Honig, 2003, "The Role of Social and Human Capital Among Nascent Entrepreneurs", Journal of Business Venturing, Vol. 18, pp. 301-331.

Dunn T. and D. Holtz-Eakin, 2000, "Financial Capital, Human Capital and the Transition to Self-Employment: Evidence form Intergenerational Links", Labour Economics, Vol. 18, No. 2, pp. 282-305.

Dupas P. and J. Robinson, 2009, "Savings Constraints and Microenterprise Development: Evidence from a Field Experiment in Kenya", National Bureau of Economic Research, Working Paper No. 14693, in http:/ / www.nber.org/papers/w14693. 
Evans D.S. and B. Jovanovic, 1989, “An Estimated Model of Entrepreneurial Choice Under Liquidity Constraint", Journal of Political Economy, Vol. 974, pp. 808-827.

Evans D. and L. Leighton, 1989, "Some Empirical Aspects of Entrepreneurship", American Economic Review, Vol. 793, pp. 519-535.

Evans D.S. and L.S. Leighton, 1990, "Small Business Formation by Unemployed and Employed Workers", Small Business Economics, Vol. 79, pp. 519-535.

Fafchamps M., 2000, "Ethnicity and Credit in African Manufacturing", Journal of Development Economics, Vol. 61, pp. 205-235.

Fairlie R.W. and B.D. Meyer, Autum, 1996, "Ethnic and Racial Self-Employment Differences and Possible Explanations", The Journal of Human Resources, Vol. 314, pp. 757-793.

Fay M. and L. Williams, 1993, "Gender Bias and the Availability of Business Loans", Journal of Business Venturing, Vol. 8, No. 4, pp. 363-376.

Groysberg B., A. Ashish Nanda and M. J. Prats, 2007, “Does Individual Performance Affect Entrepreneurial Mobility? Empirical Evidence from the Financial Analysis Market", NBER Working Paper Series, No. 13633.

Glocker D. and V. Steiner, 2007, "Self-Employment: A Way to End Unemployment? An Empirical Evidence from German Pseudo-Panel Data", IZA Discussion Paper, No. 2561, January.

Hamilton B.H., 2000, “Does Entrepreneurship Pay? An Empirical Analysis of the Returns to Self-Employment", The Journal of Political Economy, Vol. 1083, pp. 604-631.

Herrington M., M. von Broembsen, E. Wood, R. Scheepers and D. Shay, 2005, Global Entrepreneurship Monitor: South African Report 2005, UCT Centre for Innovation and Entrepreneurship, Graduate School of Business at the University of Cape Town.

Holtz-Eakin D., D. Joulfaian and H.S Rosen, 1994, "Entrepreneurial Decisions and Liquidity Constraints", Rand Journal of Economics, Vol. 232, pp. 334-347.

Holtz-Eakin D., D. Joulfaian and H.S. Rosen, 1994, "Sticking It Out: Entrepreneurial Decisions and Liquidity constraints", Journal of Political Economy, Vol. 102, pp. 5375.

Holmes T. J. and J.A. Jr. Schmitz, 1990, "A Theory of Entrepreneurship and Its Application to the Study of Business Transfers", International Journal of Industrial Organization, Vol. 12, pp. 549-568.

Irvin D. and J.M. Scott, 2008, "Barriers to Raising Bank Finance Faced by SMEs", Queen's University Management School Working Paper Series, Working paper No: MS_WPS_MAN_08_3.

Khavul S., G.D. Bruton and E. Wood, 2009, "Informal Family Business in Africa”, Entrepreneurship Theory and Practice, Vol. 33, No. 6, pp. 1219-1238.

Kirkwood J., 2009, "Motivational Factors in a Push-Pull Theory of Entrepreneurship", Gender in Management: An International Journal, Vol. 24, No. 5, pp. 346-364. 
Kon Y. and D.J. Storey, 2003, "A Theory of Discouraged Borrowers", Small Business Economics, Vol. 21, No. 1, pp. 37-49.

Korosteleva J. and T. Mickiewicz, 2009, "Start-up Financing: A Comparatives Perspective", UCL SSEES, Centre for the Study of Economic and Social Change in Europe Economics, Working Paper, No. 96.

Lehohla P., 2006, The Survey of Employers and Self-employed: September 2005, South Africa Statistical Release, P0276.

Lerner M., C.B. Brush. and R. Hisrich, 1997, "Israeli Women Entrepreneurs: An Examination of Factors Affecting Performance", Journal of Business Venturing, Vol. 13, No. 4, pp. 315-339.

Lindh T. and H. Ohlsson, 1998, "Self-Employment and Wealth Inequality", Review of Income and Wealth, Vol. 44, pp. 25-42.

Marlow S. and S. Carter, 2006, "If You Don't Ask You Don't Get! Women, Self-Employment and Finance", paper presented to Warwick Business School Small Firms Finance Conference, May, Coventry.

Mandelman F. and G.V. Montes-Rojas, 2009, "Is Self-employment and Micro-Entrepreneurship a Desired Outcome?", World Development, Vol. 372, pp. 1914-1925.

Menzies T.V., M. Diochon, Y. Gasse and S. Elgie, 2006, “A Longitudinal Study of the Characteristics, Business Creation Process and Outcome Differences of Canadian Female vs. Male Nascent Entrepreneurs", Entrepreneurship Management, Vol. 2, pp. 441-453.

Minniti M. and P. Arienus, 2003, Women in Entrepreneurship, United Nations Report.

Minniti M. and C. Nardone, 2007, “Being in Someone Else's Shoes: The Role of Gender in Nascent Entrepreneurship", Small Business Economics, Vol.28, pp. 223-238.

Mitchell B.C., 2004, "Motives of Entrepreneurs: A Case Study of South Africa", Journal of Entrepreneurship, Vol. 13, No. 1, pp. 168-183.

Muravyev A., O. Talavera, and D. Schäferf, 2009, “Entrepreneurs' Gender and Financial Constraints: Evidence from International Data", Journal of Comparative Economics, Vol. 37, pp. 270-286.

Orhan M. and D. Scott, 2001, "Why Women Enter into Entrepreneurship: An Explanatory Model", Women in Management Review, Vol. 16, No. 5, pp. 232-247.

Rissman E.R., 2003, "Self-Employment as an Alternative to Unemployment", Federal Reserve Bank of Chicago, WP 2003-34.

Reynolds P.D., W.D. Bygrave, E. Autio, L.W. Cox and M. Hay, 2002, Global Entrepreneurship Monitor, 2002 Executive Report, Babson College, London Business School and Kauffman Foundation.

Robichaud Y., J.E. Zinger and R. Le Brasseur, 2007, “Gender Differences Within Early Stage and Established Small Enterprises: An Exploratory Study", International Entrepreneurship Management Journal, Vol. 3, pp. 323-343.

Rospabé S., 2001, An empirical evaluation of gender discrimination in Employment, occupa- 
tion attainment and wage in South Africa in the late, School of Economics Development Policy Research Unit University of Cape Town, SA.

Sabarwal S. and K. Terrell, 2008, "Does gender matter for firm performance? Evidence from Eastern Europe and Central Asia", Discussion Paper No. 3758, Institute for the Study of Labor (IZA).

Ucbasaran D., P. Westhead, and M. Wright, 2004, "Human Capital Based Determinants of Opportunity Identification", Frontiers of Entrepreneurship Research, Wellesley, M.A: Babson College, pp. 430-444.

Verheul I. and R. Thurik, 2001, "Start-Up Capital: Does Gender Matter?”, Small Business Economics, Vol. 16, pp. 329-345.

Verheul I., A. Van Stel and R. Thurik, 2008, Explaining Female and Male Entrepreneurship at the Country Level, Erim Report Series Research in Management.

Wagner J., 2005, «Nascent Necessity and Opportunity Entrepreneurs in Germany Evidence from the Regional Entrepreneurship Monitor (REM)", Working Paper $n^{\circ}$ 10, University of Lüneburg Working Paper Series in Economics.

Walker D. and B.E. Joyner, 1999, “ Female Entrepreneurship and the Market Process: Gender-Based Public Policy Considerations", Journal of Developmental Entrepreneurship, Vol. 4, No. 2, pp. 95-116.

Wit G. and F. Van Winden, 1989, "An Empirical Analysis of Self-Employment in the Netherlands", Small Business Economics, Vol. 1, No. 4, pp. 263-272.

\section{Résumé:}

Cet article vise à analyser la nature l'entrepreneuriat sud-africaine et à évaluer dans quelle mesure les obstacles et les contraintes de liquidité rencontrées par les femmes en particulier peuvent différer de celles rencontrées par les hommes entrepreneurs pendant la phase de création de l'entreprise. Cette étude montre que les femmes entrepreneuriales dans le secteur informel étant moins éduquées et plus soumises au chômage que leurs homologues masculins ont été "poussées" dans l'activité entrepreneuriale pour des raisons de nécessité financière. Elles semblent ainsi avoir plus de difficultés que les hommes à accumuler suffisamment d'apports personnels pour démarrer leur entreprise. Elles comptent ainsi plus fréquemment sur des stratégies d'accès aux crédits auprès des tontines ou des prêteurs à gage que les hommes. 
